\title{
CONTRIBUTIONS TO THE METHODICS IN HERRING-INVESTIGATIONS
}

BY

EINAR LEA.

\section{GROWTH-MEASUREMENTS.}

If we examine the scale-covering of a number of small and large herrings we will find that the different individuals vary to a certain extent in the shape, number and situation of their scales. The shape of the scales may differ from the prevalent form, the number of scales in a specified row may vary slightly, and a single scale or row of scales may sometimes be found on one of the animals rather higher up or lower down than usual. But in the main a herring's scale-covering is composed of elements that will be met with again in all other herrings. If we take a row of scales along the length of the fish we shall find one scale placed regularly over every myomer; and not till we come to the portion immediately anterior to the caudal fin do anomalies occur, the scales there having a tendency to be somewhat irregularly placed.

On comparing the scale-covering of a young herring with that of an old individual we will see after a mere superficial observation that the scales of the latter have become larger, whereas their number and situation remain the same.

We are accordingly to all extents and purposes justified in assuming that the scales are organs whose growth keeps pace with the growth of the herring; and that the growth-zones on the scale, which give a lasting picture of its development, can also serve to determine the growth of the fish itself.

To establish this point I have undertaken a series of measurements of small and large herrings. As the first preliminary measurements seemed to indicate that the scale grew proportionally faster than the total length of the animal, and that this might be due to age-variations in the growth of the head and caudal fin, $I$ measured, in addition to linear dimension $V$ on a specified scale and the total-length of the fish $L$, the length of the herring's scale-covered portion $T$ measured from the posterior edge of the 


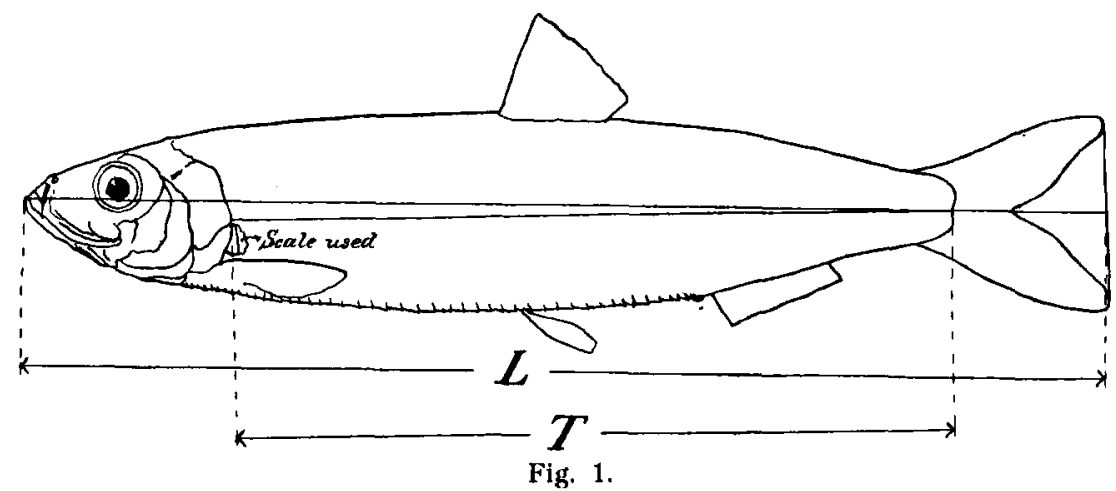

gill-cover to the commencement of the median caudal fin-ray (see Figs. 1 and 2). The scale I selected is a large one and has a characteristic shape; and it is moreover easily found as it is situated just posterior to the suboperculum. These measurements are shown in table I, where there are headings for $\mathrm{L}, \mathrm{T}$ and $V$ in $\mathrm{mm}$, and for the fractions $\frac{L}{T}, \frac{L}{V}$ and $\frac{T}{V}$. If the scale grows in direct proportion to the total-length, the fraction $\frac{\mathrm{L}}{\mathrm{V}}$ must be constant for young and old animals; and similarly, if the scale grows in proportion to dimension $T$ the fraction $\frac{T}{V}$ must be constant. Let us neglect for the present individual variations, and consider the averages in the following table:

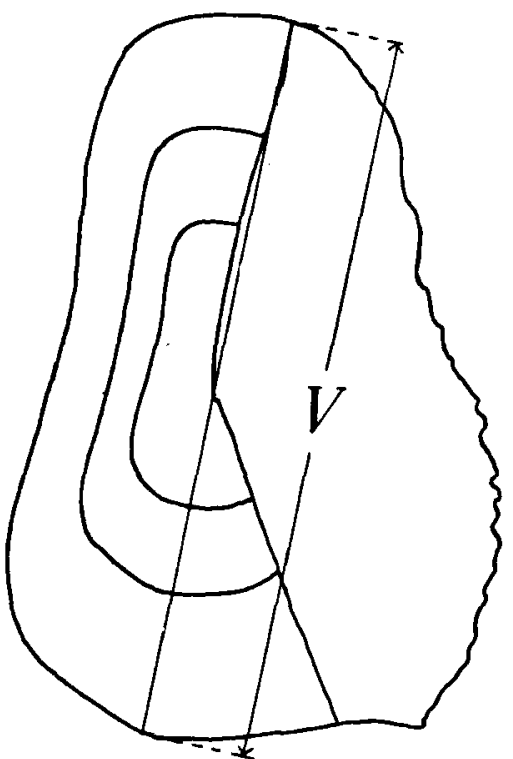

Fig. 2.

\begin{tabular}{c|c|c|c|c}
\hline Age of the herrings & $\begin{array}{c}\text { Number of } \\
\text { observations }\end{array}$ & $\frac{\mathrm{L}}{\mathrm{T}}$ & $\frac{\mathrm{L}}{\mathrm{V}}$ & $\frac{\mathrm{T}}{\mathrm{V}}$ \\
\hline 1 Year & 74 & 1.57 & 29.7 & 18.9 \\
2 Years & 36 & 1.56 & 29.0 & 18.5 \\
3 & 2 & 1.54 & 27.1 & 17.6 \\
4 & 11 & 1.52 & 27.4 & 18.1 \\
5 & 33 & 1.52 & 28.7 & 18.9 \\
6 & 218 & 1.52 & 28.3 & 18.6 \\
7 & 19 & 1.51 & 28.5 & 18.9 \\
8 & 2 & 1.51 & 28.4 & 18.6 \\
9 & 3 & 1.50 & 27.9 & 18.5 \\
10 & 6 & 1.51 & 28.6 & 19.1 \\
11 & 7 & 1.50 & 27.8 & 18.6 \\
12 & 1 & 1.50 & 28.3 & 18.9 \\
\hline
\end{tabular}


It will be seen here that there is a slight age-variation in the fractions $\frac{L}{T}$ and $\frac{L}{V}$ whereas the fraction $\frac{T}{V}$ shows practically the same value for the year-classes where the number of observations makes the averages reliable. As the ratio $\frac{L}{V}$ diminishes with increase of age the scale grows relatively quicker than dimension $\mathrm{L}$, whereas the scale and dimension $\mathrm{T}$ grow in direct proportion to each other.

The age-variation in the fraction $\frac{\mathrm{L}}{\mathrm{V}}$ must under these circumstances be due to the fact that the head and caudal fin are relatively greater in young animals than they are in old ones. And we would in actual fact get the same value of the fraction $\frac{\mathrm{L}}{\mathrm{V}}$ for both young and old animals, if we could imagine the young herrings furnished with heads and caudal fins of proportionately the same size as those of the old ones $\left(\frac{\mathrm{L}}{\mathrm{V}}=\right.$ ca. 28.1).

These measurements show accordingly that the scale we have made use of is an organ, which in size conforms to the same conditions as other organs and dimensions of the herring. And as we can see from the scale's growth-zones how large it was at the different periods of development, so we can make deductions regarding the size of the herring at its various periods of growth with an accuracy that is limited by the individual variability in the ratios $\frac{L}{V}$ and $\frac{T}{V}$. By measuring the size of the scale as far as the 1st, 2nd, and succeeding winter-rings (which we will call respectively $v_{1} v_{2} \ldots$ ) and multiplying these sizes by the average 18.67, we determine the length of the herring's scale-covered portion in the corresponding winter-periods (these sizes we will designate $T_{1} T_{2} \ldots$ ) and we thus get $T_{1}=v_{1} \times 18.67 ; T_{2}=v_{2} \times 18.67 \ldots$ It is also possible to calculate $T_{1} T_{2}$ by an easier method; since, owing to the ratio $\frac{T}{V}$ being the same for both young and old animals, we can take $\frac{T_{1}}{v_{1}}=\frac{T}{V}$, and therefore $T_{1}=T \frac{v_{1}}{V}$; and thus avoid using the constant 18.67.

The probable error in these measurements is due to the individual variability in the ratio $\frac{\mathrm{T}}{\mathrm{V}}$. For the 1-year groups in the table the probable error was found to be about $7 \%$ of the average; and a calculated value $T_{1}=100 \mathrm{~mm}$ will thus involve a probable error of $7 \mathrm{~mm}$. 
In the formula $T_{1}=T \frac{v_{1}}{V}$ the constant 18.67 , which is characteristic of the scales hitherto made use of, does not occur. The question now arises: can other scales be made use of in the same manner, or do other scales show different modes of growth in relation to $\mathrm{L}$ and $\mathrm{T}$ ?

The measurements of Heincke and other investigators demonstrate that the different parts of a herring's body grow differently at different periods of its life. It is therefore quite possible that scales from other parts of the body differ in mode of growth. To test this I have measured series of scales. These measurements disclosed conditions that served materially to explain the individual variation in the size of scales. They showed namely that a considerable part of the individual variation in the size of scales is due to other causes than the variability of mode of growth.

Before we proceed to discuss these measurements numerically we will consider Figs. 3,4 and 5, which delineate graphically the scale-measurements of 3 series of scales from the same herring. The numbers along the abscissae denote the locationnumbers of the scales in the series, reckoned in a backward direction from the gill-cover; the uppermost curve in each figure connects the ordinates that represent the length of the scale measured from its centre to as far as the edge, along the zigzag line (the median line in Mr. KNuT DaHL's brochure "The scales of the herring " (1)). The other curves represent the same dimension as far as to the 1st winter-ring, 2nd winter-ring, \&c. In Fig. 3 we have measurements from the 7 th row on the left side reckoning from the belly upwards; Fig. 4 gives measurements from the same row on the right side; while Fig. 5 delineates the measurements of the 6th row from the belly on the right side, with the numbers so arranged that scale No. 10 , for instance, is located on the same myomer as scale No. 10 in Fig. 4.

If we compare Figs. 3 and 4 we will notice that the size of scales on the right and left sides do not exactly correspond. For instance if a scale on one side of the fish is larger than either of its neighbour-scales it does not follow that the same will be the case with the corresponding scale on the other side. Again a comparison of Figs. 4 and 5 makes it clear that variations in the 7 th row do not involve corresponding variations in the 6th row on the same side.

We have now to investigate the variations of the scales from one growth-period to the other by comparing the curves of the winter-rings; and we will see that a scale whose size deviates 
from that of its neighbour-scale has had the same mode of deviation right back to the first winter of the animal's life. Only in a few cases are there unimportant exceptions. If then the other scales vary in size similarly to the one which was used for the measurements in table I, and my measurements have satisfied

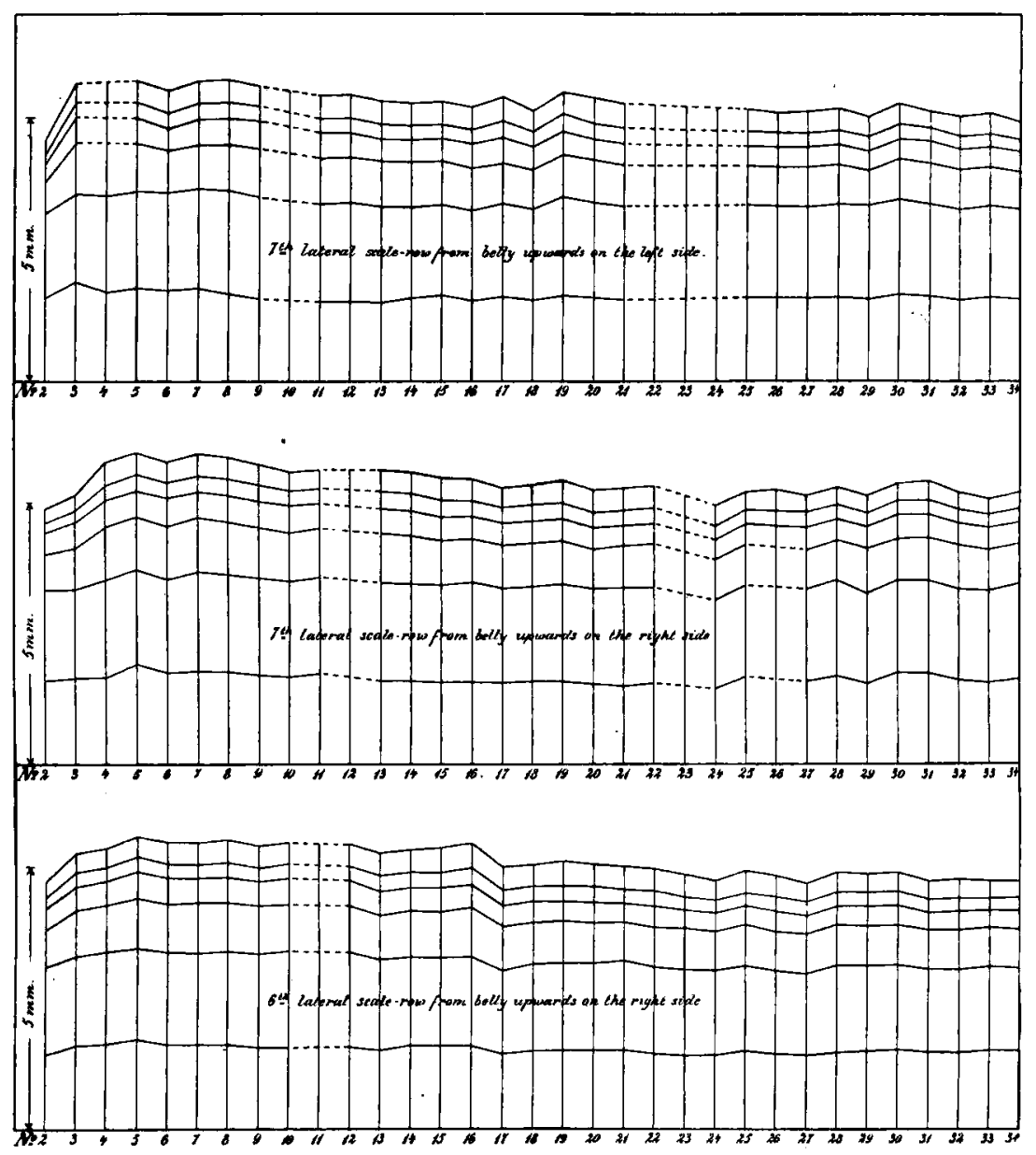

Fa 3,4and 5. Moesurements of 3 scale-series. Broken euroos indicate, that scales kave tached or been defect.

me that such is the case, most of the individual variation in the size of the scales must be due to other circumstances than variable growtl. If growth were the cause, then a scale which in a given year was let us say $17 \mathrm{~T}$ might be perhaps in the next year $\frac{1}{20} \mathrm{~T}$, and the curves of the winter-rings would in that case be quite independent of each other. 
To express this in figures $I$ measured the ratio $\frac{v_{1}}{V}$ in scales taken from the region behind the gill-cover, and calculated the probable error expressed in percentage of the average (see table II where the numerators in the fractions are shown under the heading $l_{1}$, while the denominator is put at 291). Although this method involved the risk of getting scales with a different mode of growth, seeing that they were taken from several myomers, still the probable error was only $2.4 \%$ of the average. Employing this on the example previously mentioned - a length of $100 \mathrm{~mm}$ - we get an error of $2.4 \mathrm{~mm}$, which is about $\frac{1}{3}$ of the error we obtained according to the formula $T_{1}=v_{1} \times 18.67$.

The formula $\mathrm{T}_{1}=\mathrm{T} \frac{\mathrm{v}_{1}}{\mathrm{~V}}$ thus holds good for other scales than that hitherto used and as it gives far more exact results than the formula $T_{1}=v_{1} \times 18.67$, it is therefore to be preferred. If we wish to find the total length in the respective growth-periods $\mathrm{L}_{1} \mathrm{~L}_{2} \ldots$ we must multiply $\mathrm{T}_{1} \mathrm{~T}_{2} \ldots$ by the average-number which denotes how many times greater $L_{1} L_{2} \ldots$ is than $T_{1} T_{2} \ldots$ (see the table on page 6).

An approximate value for $L_{1} L_{2} \ldots$ which we will call $\mathrm{l}_{1} \mathrm{l}_{2} \ldots$ may be obtained by disregarding the age-variation in the ratio $\frac{L}{T}$ and taking $l_{1}=L \frac{v_{1}}{V} ; l_{2}=L \frac{v_{2}}{V} \cdots$ As these formulae are employed in the measurements that I have undertaken for the International Council I will discuss them more fully. It is obvious that they presuppose a directly proportional growth between $L$ and $V$. This presupposition does not quite hold good, and the question now arises what error will result therefrom. Let us take $\frac{L_{1}}{T_{1}}=a_{1}(1)$ then in the same way $\frac{L}{T}=a(2)$ : we have already got $l_{1}=L \frac{v_{1}}{V}(3)$ and $T_{1}=T \frac{v_{1}}{V}$ (4) so that from a combination of these we get

$$
\mathrm{L}_{1}=\mathrm{l}_{1} \frac{\mathrm{a}_{1}}{\mathrm{a}}(5) \text { and } \mathrm{l}_{1}=\mathrm{T}_{1} \mathrm{a}(6) \text {. }
$$

From equation 5 it appears that the correct value of $L_{1}$ is got by multiplying the calculated $l_{1}$ by a fraction whose numerator is the ratio $\frac{\mathrm{L}_{1}}{\mathrm{~T}_{1}}$ and whose denominator is the ratio $\frac{\mathrm{L}}{\mathrm{T}}$. To calculate the lengths, at the formation of the $2 \mathrm{nd}, 3 \mathrm{rd}, \ldots$ winter rings similar equations may be worked out. The individual values of $a_{1} a_{2} \ldots$ are of course unknown; but the average values of the different year classes can be obtained, and will serve to determine the correction-multiplicator. 
The following table shows the numerical values of

$$
\frac{a_{1}}{a_{2}}, \frac{a_{1}}{a_{3}}, \ldots \frac{a_{2}}{a_{3}}, \ldots
$$

worked out in accordance with the measurements in table I.

Correction-multiplicatores for the formulae $l_{1}=L \cdot \frac{v_{1}}{V}, I_{2}=L \cdot \frac{v_{2}}{V} \cdots$

\begin{tabular}{|c|c|c|c|c|c|}
\hline$\frac{a_{1}}{a_{2}}=1.01$ & $\begin{array}{l}\frac{a_{1}}{a_{3}}=1.02 \\
\frac{a_{2}}{a_{3}}=1.01\end{array}$ & $\begin{array}{l}\frac{a_{1}}{a_{4}}=1.04 \\
\frac{a_{2}}{a_{4}}=1.03 \\
\frac{a_{3}}{a_{4}}=1.02\end{array}$ & $\begin{array}{l}\frac{a_{1}}{a_{5}}=1.04 \\
\frac{a_{2}}{a_{5}}=1.02 \\
\frac{a_{3}}{a_{5}}=1.01 \\
\frac{a_{4}}{a_{5}}=1.00\end{array}$ & $\begin{array}{l}\frac{a_{1}}{a_{B}}=1.04 \\
\frac{a_{2}}{a_{b}}=1.02 \\
\frac{a_{3}}{a_{6}}=1.01 \\
\frac{a_{4}}{a_{6}}=1.00\end{array}$ & $\begin{array}{l}\frac{a_{1}}{a_{7-11}}=1.05 \\
\frac{a_{2}}{a_{7-11}}=1.03 \\
\frac{a_{3}}{a_{7-11}}=1.02 \\
\frac{a_{4}}{a_{7-11}}=1.01\end{array}$ \\
\hline
\end{tabular}

The multiplicator, it will be noticed, does not attain higher values than 1.05 .

The corrections in the values $l_{1} l_{2} \ldots$ which can be made in this way enable us to compare these calculated lengths with directly measured lengths of smaller herrings of a corresponding age, and for this purpose they are well-adapted. However equation 6 shows that $l_{1} l_{2} \ldots$ are merely the same as $T_{1} T_{2} \ldots$ multiplied by a factor a, which according to the table on page 6 is practically the same for all grown animals. It is therefore quite unnecessary to introduce a correction in cases where one has to study the growth of grown animals.

We have now the means of determining $L_{1} L_{2} \& c$, by measurements of scales situated close to the gill-cover; and, utilising these values as standard values, we can proceed to study the conditions of scales from other parts of the body, employing the formula $l_{1}=L \frac{v_{1}}{V}, l_{2}=L \frac{v_{2}}{V}, \ldots$ It is quite possible we might find scales that grew in direct proportion to the total length and which accordingly would give us values $L_{1} L_{2} \ldots$ without making use of any correction-multiplicator.

To ascertain this I have taken measurements of the scale on every 4th myomer of a herring (see table II). The averages for each myomer will be found in the following text-table (page 12).

As standard value I have taken the corrected average of the measurements of 10 scales from the 1 st myomer. The values under the headings $t_{2} t_{3} \ldots$ denote the increment in each year and are obtained by subtraction: $t_{2}=l_{2}-l_{1} ; t_{3}=l_{3}-l_{2} \ldots$ 


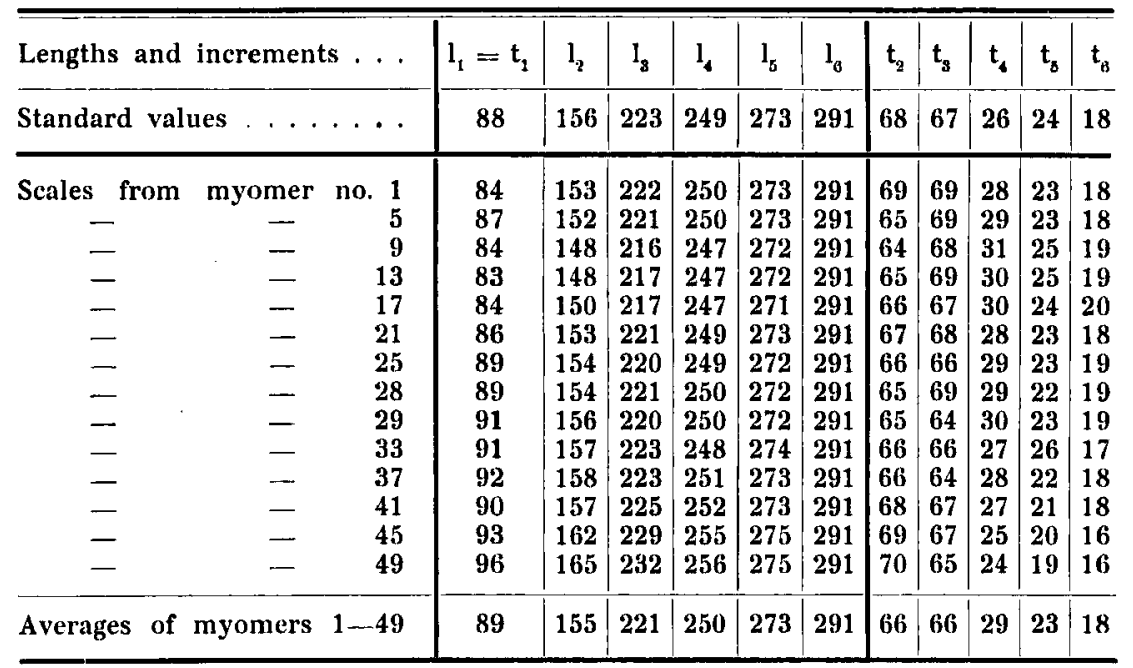

If we look first at the values for $l_{1} l_{2} \& c$, , we will see that there is to begin with a sinking tendency till we come to myomer No. 13 where the values rise until they become maximal in the case of the posterior myomers. An examination of the values under the headings $t_{1}=l_{1} t_{2}=t_{3} \ldots$, where each year's growth is given apart, shows us that this sinking and rising is chiefly confined to the first and second year of the herring's existence. In the case of the three last years the values are lowest for the posterior myomers. The scales from the 1 st to the 21 st myomer give us figures so closely according, that the correction table worked out for the 1st myomer can quite well be employed for these scales, which are the ones chiefly utilised when taking scalesamples. The values from myomers $25-28$ are in their uncorrected form fairly like the corrected values obtained from myomer No. 1. The largest and most distinct scales on these myomers are located in the neighbourhood of the herring's lateral line directly under the posterior half of the dorsal fin.

It is clear from the preceding remarks that the length of a herring in the previous winter-periods of its existence can be calculated in various ways:

1) by examining scales situated in the anterior portion of its body and adopting the correction due to the age-variation in the fraction $\frac{\mathrm{L}}{\mathrm{T}}$.

2) by examining scales from myomers 25-28, without any correction at all.

3) by examining several scales from different parts of the body, and taking their average without correction. 
4) by examining a clearly-marked scale selected at random without any correction.

If not more than one scale is taken, the question arises: what accuracy do we get from alternatives 1,2 and 4 . With a view to throwing light upon this point I calculated the probable error, by measuring scales from the region just behind the gillcover, scales from myomers 25-29, and scales taken from all parts of the body. The figures given below show the probable error of $l_{1}$ in these measurements; since it appeared that this value was the most variable, and that deviations for $l_{2} l_{3} \& c$., were to a great extent dependent on deviations in $l_{1}$.

$$
\text { Probable error of a determination } l_{1}=88 \mathrm{~mm} \text {. }
$$

Scales from the anterior part of the body ............ $2 \mathrm{~mm}$

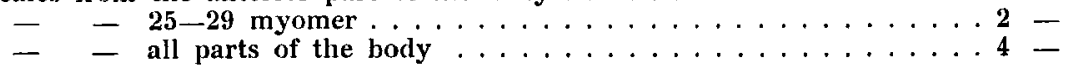

Obviously alternatives 1 and 2 give very exact results, but alternative 2 is to be preferred as it does not presuppose any correction. Alternative 4 likewise gives values that are useful in many cases. The tables show that in 50 cases out of 100 the measurements of every distinct scale will give values that do not deviate more than $4 \mathrm{~mm}$ from the true average.

With regard to the measurement-dimension on the scale selected, I recommend dimensions along a line taken fairly perpendicularly from the scale's centre on the boundary line between the striated and smooth portion of the scale (see Fig. 6). I have moreover taken the measurements of a particular scale by marking off the measurement-dimension

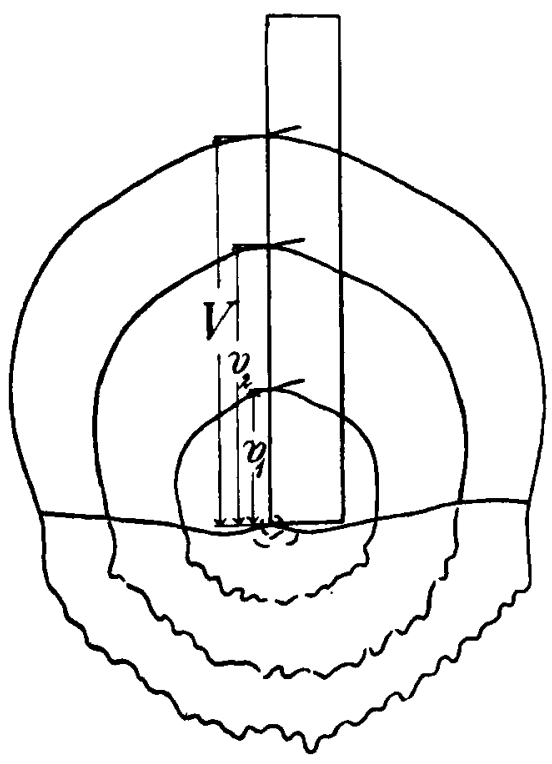

Fig. 6. in 10 different directions, and found that direction is rather immaterial if the centre of the scale is clearly established.

Instances of growth-measurements will be found in the following chapter. I would particularly call attention to the graphical delineation in Fig. 8. 


\section{DETERMINATION OF AGE.}

As the growth-measurements discussed in the preceding chapter may in combination with other data serve to illustrate our method of determining age, I will endeavour to summarise the results of my investigations into the character of the so-called winter-rings.

The first question I will endeavour to answer is the following: Have all scales belonging to the same herring an equal number of winter-rings? To decide this point I selected herrings whose scales had a distinct structure and where accordingly complications did not arise owing to the presence of so-called secondary rings which I shall allude to subsequently. From these herrings I extracted quantities of scales (in some cases as many as 200) from different parts of their bodies. An investigation of them showed firstly that all scales on the actual body have an equal number of winter-rings, and secondly that the distance between these rings relative to each other is so far constant that scales from no matter what portion of the body may be employed for determining the growth of the herring. Instances of such parallel investigations will be found in table II and in the graphical delineations in Figs. 3, 4 and 5. Exceptions to this rule occur in the regenerated scales and also in scales which have been displaced from their true location. A scale of this latter description is shown in Fig. 7.

There are even some minute scales on the caudal fin itself, though they show practically no annual-ring structure and are to all extents and purposes unserviceable. I merely mention them here, because they have occurred in some of the scale-samples.

None of the sources of uncertainty hitherto mentioned are really of any account, since the structure of the scales gives the 
necessary clues. But it is quite another matter with the accessory or secondary rings, by which are meant the ring-formations that are often visible in the broad growth-zones of a scale. These are generally faintly marked as compared with the winter-rings. Still now and then they are able to causc considerable confusion, and the question arises, how are we to avoid the uncertainty due to their appearance. I have examined series of scales where accessory rings occurred, and found that they to a very great extent answer to the name bestowed upon them by Mr. KNUT DaHL. Their occurrence is different in the different scales, and in doubtful cases accordingly we can distinguish them by examining several scales. To make sure of this and at the same time to obtain means of ascertaining what part one's personal judgment plays in determination of age, I got a number of parallel observations made. Mr. KNUT DaHL very kindly determined the ages of 100 herrings, out of which I had in 55 cases only prepared one scale; though from the remaining 45 herrings I had taken 3 scales pr. fish. I myself had made the same determinations previously. On comparing our figures we found

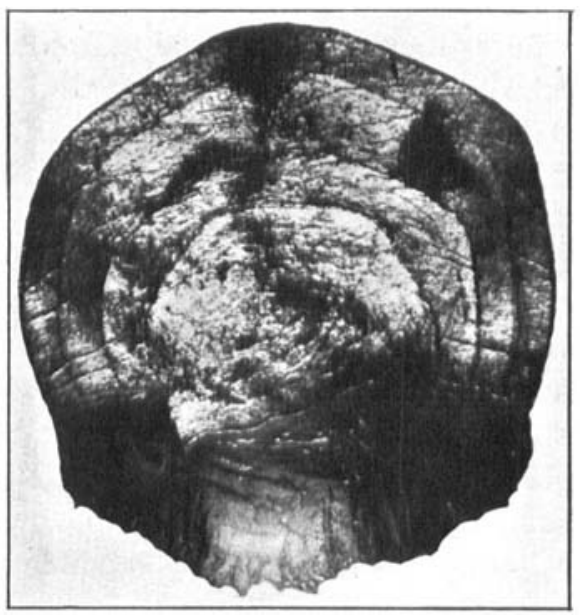

Fig. 7.

Anomaleus scale. Regenerated in 2nd summer and displaced in 2nd winter. a discrepancy of 1 year in 3 instances, where there was only one scale to examine; but our observations were absolutely in accordance in the case of the herrings from which I had taken 3 scales. On another occasion Dr. HJonT went through the growth-measurements of several hundred herrings, and his findings coincided with mine in every case but one, where I had undoubtedly made a mistake. The only conclusion to be drawn from these parallel observations is that the sources of error in determining age are small and of no significance for the biological problems to be elucidated.

It is also very often a good plan to alter the light and enlargement. It is important moreover to clean the scales thoroughly and to subject them to a careful preparation. When many investigations have to be made I lay the scales in alcohol with a covering of glass over them; but when I wish to prepare 
scales for subsequent examination, I affix them to an object-glass with a solution of glycerine and white of egg (70\% white of egg $30 \%$ glycerine and a little camphor), placing the smooth side of the scale against the glass and thus avoiding having any sticky substance on the striated side. If a preparation such as I have described is heated up to about $80^{\circ} \mathrm{C}$. the white of egg coagulates, and the scale when required may be either imbedded in glycerine gelatine, or laid in alcohol.

We have further important evidence of the practical advantage of our method of age-determination in the close agreement in regard to distribution of year-classes which we find in cases where there are several samples of well-characterised herringgroups from the same year. I would refer the reader to the published analyses (see K. DAHL's brochure: "The scales of the herring " (1) and Dr. Huont's "Circular to the Members of Committee $A$ « (2) and »Proposal for Organisation of the International Investigations of the Herring Fisheries (3)), where certain yearclasses predominate in many samples; and I have only to add that my analyses were quite in accordance with them. Very characteristic in this respect are the analyses of samples of the typical Norse spring-herring, where the year-class which formed its first winterring in 1904 preponderates largely over all the other year-classes. Similar conditions appear in the case of other localities, as will be seen from the tables given below.

Norweglan spring herrings.

\begin{tabular}{|c|c|c|c|c|c|c|c|c|c|c|c|c|c|}
\hline \multirow{2}{*}{$\begin{array}{l}\text { Locality and date of } \\
\text { capture }\end{array}$} & \multirow{2}{*}{ 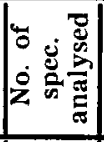 } & \multicolumn{12}{|c|}{ Number of specimens in the year-classes } \\
\hline & & $\stackrel{\mathscr{8}}{\mathscr{\rho}}$ & 哭 & Ë & $\mid \begin{array}{c}\stackrel{n}{8} \\
\stackrel{2}{2} \\
\end{array}$ & 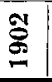 & 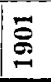 & $\underset{8}{\Phi}$ & $\underset{8}{\infty}$ & $\stackrel{\infty}{\infty}$ & 点 & $\mathscr{\infty}$ & $\stackrel{10}{\infty}$ \\
\hline $60^{\circ} 30^{\prime}$ N. $3^{0} 30^{\prime}$ E. $\quad 18 / 91909$ & 380 & 1 & 15 & 197 & 38 & 26 & 34 & 22 & 25 & 17 & 3 & 1 & 1 \\
\hline $60^{\circ} 32^{\prime} \mathrm{N}, 3^{0} 30^{\prime}$ E. $1 / 101909$ & 359 & 2 & 27 & 246 & 33 & 17 & 8 & 7 & 9 & 2 & 3 & 3 & 2 \\
\hline $61^{\circ} 20^{\prime}$ N. $5^{\prime \prime} 0^{\prime}$ E. $\quad 18 / / 31909$ & 291 & 3 & 33 & 218 & 19 & 2 & 3 & 6 & 7 & 1 & & & \\
\hline
\end{tabular}

Herrings from the fjords of the Faroes.

\begin{tabular}{|c|c|c|c|c|c|c|c|c|c|c|c|}
\hline \multirow[b]{2}{*}{ Locality and date of capture } & \multirow{2}{*}{ 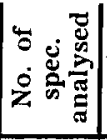 } & \multicolumn{10}{|c|}{ Number of specimens in the year-classes } \\
\hline & & 足 & $\stackrel{5}{8}$ & 导 & 哭 & $\underset{\Xi}{\stackrel{\Xi}{\sigma}}$ & 兽 & $\underset{\tilde{g}}{\stackrel{9}{\Xi}}$ & $\overline{8}$ & 18 & $\mid \underset{\infty}{\not \infty}$ \\
\hline 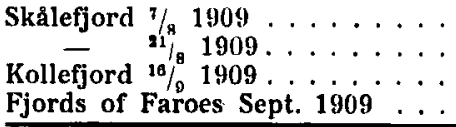 & $\begin{array}{r}192 \\
139 \\
91 \\
640\end{array}$ & $\begin{array}{r}13 \\
25 \\
3\end{array}$ & $\begin{array}{r}170 \\
112 \\
87 \\
595\end{array}$ & $\begin{array}{l}3 \\
2\end{array}$ & $\begin{array}{r}1 \\
12\end{array}$ & $\begin{array}{l}2 \\
7\end{array}$ & $\begin{array}{l}1 \\
2\end{array}$ & 1 & 1 & 1 & 2 \\
\hline
\end{tabular}


Mature herrings from Iceland.

\begin{tabular}{|c|c|c|c|c|c|c|c|c|c|c|c|c|c|c|}
\hline \multirow{2}{*}{$\begin{array}{c}\text { Locality and date } \\
\text { of capture }\end{array}$} & \multirow{2}{*}{ 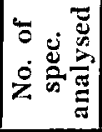 } & \multicolumn{13}{|c|}{ Number of specimens in the year-classes } \\
\hline & & $\underset{8}{20}$ & 芦 & 灾. & 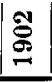 & $\overrightarrow{\sigma_{0}}$ & $\stackrel{8}{g}$ & $\mid \underset{\mathscr{\sigma}}{\stackrel{g}{\infty}}$ & $\stackrel{\infty}{\infty}$ & $\stackrel{1}{\infty}$ & 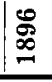 & $\begin{array}{l}10 \\
\mathscr{E} \\
\end{array}$ & $\underset{\infty}{\infty}$ & 急 \\
\hline South-Iceland $3 / 6$ & 280 & 1 & 49 & 26 & 14 & 19 & 34 & 44 & 47 & 20 & 8 & 8 & 10 & \\
\hline North-Iceland $25 / 7,1908$ & 419 & & 6 & 40 & 28 & 30 & 39 & 95 & 74 & 40 & 31 & 24 & 10 & 2 \\
\hline
\end{tabular}

These tables show us that samples from a given locality in one period of growth agree fairly closely in regard to their agecomposition, when we classify them according to the number of winter-rings on the scales. We shall now compare samples from the same locality in different years. Here too our material of Norse spring-herrings reveals characteristic conditions. The following table shows how herrings with 4 winter-rings largely preponderate in 1908. In 1909 herrings with 5 winter-rings are decidedly in the majority, while herrings with 6 winter-rings preponderate in 1910.

Norwegian spring-herrings.

\begin{tabular}{c|c|c|c|c|c}
\hline \hline $\begin{array}{l}\text { Year of } \\
\text { capture }\end{array}$ & $\begin{array}{c}\text { No. of her- } \\
\text { rings with 3 } \\
\text { winter-rings }\end{array}$ & $\begin{array}{c}\text { No. of her- } \\
\text { rings with 4 } \\
\text { winter-rings }\end{array}$ & $\begin{array}{c}\text { No. of her- } \\
\text { rings with 5 } \\
\text { winter-rings }\end{array}$ & $\begin{array}{c}\text { No. of her- } \\
\text { rings with 6 } \\
\text { winter-rings }\end{array}$ & $\begin{array}{c}\text { No. of her- } \\
\text { rings with 7 } \\
\text { winter-rings }\end{array}$ \\
\hline 1908 & 4 & 498 & 174 & 166 & 159 \\
1909 & & 2 & 248 & 68 & 23 \\
1910 & & 3 & 33 & 18 & 19 \\
\hline
\end{tabular}

I find quite analogous conditions in the ca. hes from the Faroes, where we have observations $f \cdot 1908$ and, 09 . This is shown by the following table.

Herrings from the aroes.

\begin{tabular}{|c|c|c|c|c|}
\hline $\begin{array}{l}\text { Locality and Year } \\
\text { of capture }\end{array}$ & $\begin{array}{l}\text { No. of her- } \\
\text { rings with } 0 \\
\text { winter-ring }\end{array}$ & $\begin{array}{c}\text { No. } 0^{+} \text {aer- } \\
\text { rings itl } 1 \\
\text { wint ring }\end{array}$ & $\begin{array}{l}\text { No. of her- } \\
\text { rings with } 2 \\
\text { winter-rings }\end{array}$ & $\begin{array}{l}\text { No. of her- } \\
\text { rings witl } 3 \\
\text { winter-rings }\end{array}$ \\
\hline $\begin{array}{cc}\text { Fjords of Faroes } & 1908 \\
- & 1909\end{array}$ & $\begin{array}{l}0 \\
0\end{array}$ & $\begin{array}{r}416 \\
41\end{array}$ & $\begin{array}{r}22 \\
964\end{array}$ & $\begin{array}{r}1 \\
21\end{array}$ \\
\hline
\end{tabular}

The facts already adduced make it quite clear in my opinion that one and only one winter-ring is formed each year, and that the view Dr. G. Schneider advances in his brochure Ueber die Altersbestimmung bei Heringen (4), that several winter-rings may 
be formed in a year, is quite untenable. In further support of my contention I will show a number of growth-measurements, which demonstrate that the lengths calculated from the lastformed winter-ring, in samples from 1909, have nearly the same average value as the average length of the directly measured herrings in 1908. The table below given is an example taken from the Faroe samples.

Herrings from the fjords of the Faroes Aug.-Sept. 1908 and 1909.

\begin{tabular}{l|l|l}
\hline Average length measured directly of herrings caught 4 . Aug. & $20.0 \mathrm{~cm}$. & $\begin{array}{c}416 \text { herrings } \\
\text { measured }\end{array}$ \\
$\begin{array}{c}1908, \text { with } 1 \text { winter-ring within the margin of the scales. } \\
\text { Calculated average length, at formation of } 2 \text { d winter-ring }\end{array}$ & $21.5-$ & $\begin{array}{c}964 \text { herrings } \\
\text { measured }\end{array}$ \\
$\begin{array}{c}\text { of herrings caught Aug.-Sept. } 1909 \text { with } 2 \text { winter-rings } \\
\text { within margin. }\end{array}$ & $21.5-$
\end{tabular}

Here it appears that the average length at the formation of the 2nd winter-ring is slightly higher than the average length of fish caught in August 1908 which had not yet formed their 2nd winter-ring. This is of course what we would expect to find, seeing that the fish caught on 4 th August had not yet completed their annual growth.

As a final example I will show the results of age and growth investigations in a sample of young herrings caught in the north of Norway during the autumn of 1909 . This sample can also be represented by typical Petersen-curves, and I accordingly give the analysis as a graphical delineation in Fig. 8.

The uppermost diagram shows the sample arranged in cm.groups, wherefrom we obtain a quadrimodal Petersen-curve. In the next diagram each age-group is arranged by itself, and we notice that the three first modes in the Petersen-curve correspond to the three first year-classes, while the fourth mode contains the three following year-classes. The lowest diagram shows the calculated lengths, at the formation of the 1 st and 2 nd winterrings, of the group of herrings which had formed 2 winter-rings inside of the edge of the scale and which were $2 \%$ years old. The complete accordance between all the curves in these diagrams, conclusively proves in my opinion the justice of my contention.

To determine the time during which the formation of the growth-zones takes place I occasionally investigated scales of the 1 and 2 year-old herrings which are caught at different seasons among the islands off the coast near Bergen. The samples I examined in December 1909 had a very uniform character, since 
on the scales of the smallest fish which were about 1 year old there was no winter-ring inside the edge of the scale: whereas the larger herrings that were approximately 2 years old did have

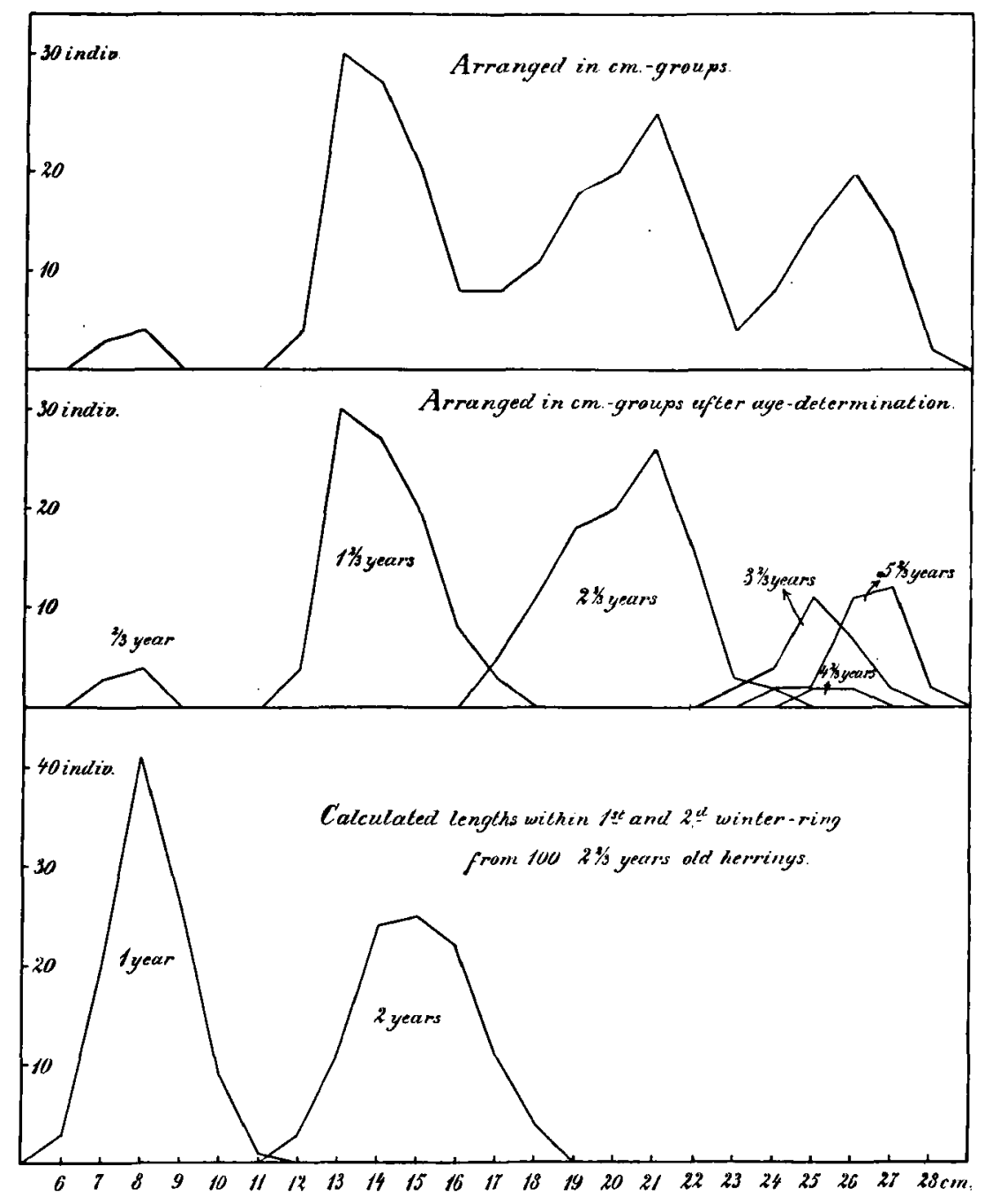

Fig. 8 . Youkg terrings from northern Norway autumn 1909.

a winter-ring. In the three first months of 1910 I was unfortunately unable to secure fish for investigation, but on $23 / 41910$ I obtained 20 herrings which I took from a catch of sprats. The two smallest of these had now developed a winter-ring just inside the edge of the scale, while the other 18 had a winter-ring well 
inside of it and a second one just within the edge. These herrings had quite obviously began their summer growth. This could clearly be seen inter alia from the fact that the winter-ring on some scales was at the very edge. along the sides, whereas it lay slightly inside of the edge in the forepart. To express in figures this newly-formed increment I calculated the percentage which the distance between the edge of the scale and the last winter-ring was of the distance between this winter-ring and the preceding one. I obtained from this an average of $12.8 \%$.

That we are dealing here with the commencement of summer-growth is certain, if we consider that in spring-herrings which have completed these periods of growth the increment between the 2 nd and 3rd winter-ring is about $80 \%$ of the increment between the 1 st and 2nd winter-ring. These small herrings have accordingly formed $\frac{12 \cdot 8}{80}$ or approximately $\frac{1}{6}$ of their summer-growth between December 1909 and 23rd April 1910, and in the case of these herrings at any rate it is unquestionable that what we have designated the winter-ring actually is one.

Mr. K. DAHL has in his paper (1) expressed the opinion that some herrings, born in late summer or autumn, possibly do not form a scale during their first winter of existence. Consequently the area inside the first winter-ring should in such herrings represent more than one years age and growth. In accordance therewith he found that in certain autumn-spawners of the Skagerrack and the North Sea the area of the scale within the first winter-ring was very large compared to consequent'zones of growth and that in this respect the scales of this autumn-spawners presented quite another picture than the scales of spring-spawners from the Norse coast.

To solve the question if this is a general feature in all summer or autumn spawners in the international area we want a very representative material, such as is not at $\mathrm{my}$ disposition. Without committing myself to any statement regarding the general conditions, I will confine myself to giving the average course of growth in the group of autumn-spawning herrings from the Cattegat which formed their first winter-ring in 1904. Herrings from this locality have been examined by Mr. HJ. BRoch (5) and by Dr. G. Schneiden, with a view to solving precisely the same question. For purposes of comparison I have given analogous figures for a sample of Norse spring-herrings. 
Averages from 80 autumn-spawners and 246 spring-spawners.

\begin{tabular}{|c|c|c|c|c|c|c|c|c|c|c|c|}
\hline \multirow{2}{*}{$\begin{array}{c}\text { Locality and date } \\
\text { of capture }\end{array}$} & \multirow{2}{*}{$\begin{array}{l}1904 \\
l_{1}=t_{1} \\
\end{array}$} & \multicolumn{5}{|c|}{$|1905| 1906|1907| 1908 \mid 1909$} & \multicolumn{5}{|c|}{\begin{tabular}{|l|l|l|l|l|l|}
1905 & 1906 & 1907 & 1908 & 1909 \\
\end{tabular}} \\
\hline & & 1 & $l_{3}$ & $1_{4}$ & $l_{5}$ & $1_{B}$ & $t_{2}$ & $\mathbf{t}_{\mathbf{y}}$ & $t_{4}$ & $\mathbf{t}_{\mathbf{5}}$ & $t_{7}$ \\
\hline $\begin{array}{l}\text { Trindelen Kattegat } 13 / 101909 . \\
6032^{\prime} \text { N. 5" } 20^{\prime} \text {.E. } 1 / 101909\end{array}$ & $\begin{array}{r}126 \\
83\end{array}$ & $\begin{array}{l}177 \\
154\end{array}$ & 213 & $\begin{array}{l}239 \\
249\end{array}$ & $\begin{array}{l}255 \\
273\end{array}$ & $\begin{array}{l}266 \\
290\end{array}$ & $\begin{array}{l}51 \\
71\end{array}$ & $\begin{array}{l}36 \\
59\end{array}$ & $\begin{array}{l}26 \\
36\end{array}$ & $\begin{array}{l}16 \\
24\end{array}$ & $\begin{array}{l}11 \\
17\end{array}$ \\
\hline
\end{tabular}

Growth-conditions are, it will be noticed, extremely remarkable and point to the desirability of further investigations along the same lines. 


\section{ABBREVIATIONS AND SIGNS}

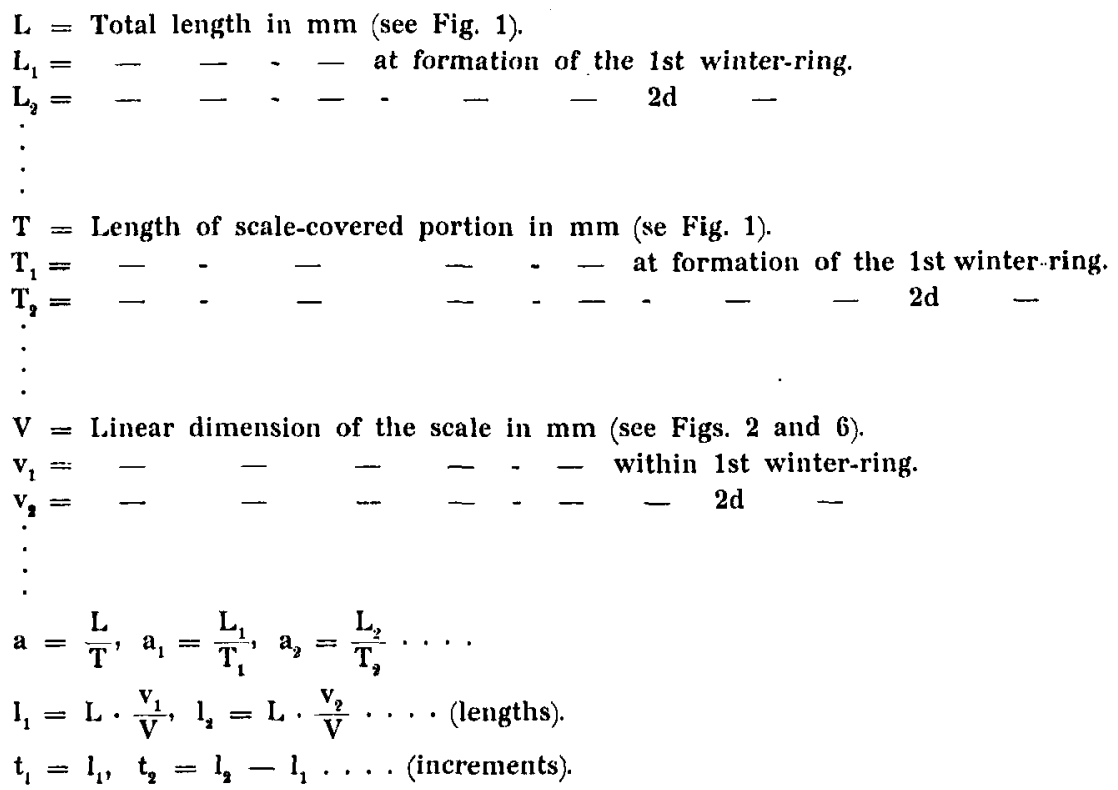




\section{LITTERATURE.}

1. Dahl, Knut. The Scales of the Herring as a Means of Determining Age, Growth and Migration. Report on Norwegian Fishery and Marine Investigations, Vol. II. 1907. No. 6.

2. Hjort, Dr. Johan. Circular to the Members of Commitee A. Hapports et Proces-verbaux, Vol. XI. 1909.

3. Hjort, Dr. Johan. Report regarding the Herring. Rapports et Proces-verbaux. Vol. XII. 1909.

4. Schneider, Dr. Guido. Ueber die Altersbestimmung bei Heringen nach den Zuwachszonen der Schuppen. Svenska Hydrograf.-biologiska Kom. Skrifter, 1910 .

5. Broch, Hjalmar. Förteckning öfver Göteborgs Museums sillsamlingar med kort vägledning i fjällundersökningsmetoden. Svenska Hydrograf.-biologiska Kom. Skrifter. III. 1908.

6. Heincke, Prof. Dr. Fr. Naturgeschichte des Herings Abhandlungen des Deutschen Seefischerei-Vereins, Bd. II. 1898.

For further litterature on the subjects see Knut Dahl, The assessment o age and growth in Fish. Internationale Revue der gesamten Hydrobiologie und Hydrographie. Bd. II. Heft 4 u. 5 . 
TABLE I.

Measurements of Norwegian spring herrings caught near Bergen during the winter $1909-1910$.

\begin{tabular}{|c|c|c|c|c|c|c|c|c|c|c|c|c|c|}
\hline \multicolumn{7}{|c|}{ Herrings with 1 winter-ring. } & \multicolumn{7}{|c|}{ Herrings with 1 winter-ring. } \\
\hline No. & L & $\mathbf{T}$ & $\frac{\mathrm{L}_{1}}{\mathrm{~T}}=\mathrm{a}_{1}$ & V & $\frac{\mathrm{L}}{\mathrm{V}}$ & $\frac{T}{V}$ & No. & L & $\mathrm{T}$ & $\begin{array}{l}\mathrm{L}_{1} \\
\mathrm{~T}_{1}=\mathrm{a}_{\mathrm{t}}\end{array}$ & V & $\frac{L}{V}$ & $\frac{T}{V}$ \\
\hline 1 & 9 & 61 & 56 & 2 & 9.7 & 9.1 & 49 & 119 & 74 & .61 & 3.6 & 33.1 & 20.6 \\
\hline 2 & 103 & 66 & & & & .8 & oU & 119 & & .57 & 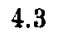 & 27.7 & 17. \\
\hline 3 & 106 & 68 & 1 & & 0.3 & 19.4 & 51 & 119 & & 1.59 & 4.0 & 29.8 & 18.8 \\
\hline 4 & 107 & 67 & 1.6 & 3.5 & 30.6 & 19.1 & 52 & 119 & 7 & .57 & 4.1 & 29.0 & 18.5 \\
\hline 5 & 107 & 69 & 1.5 & 3.7 & 29.0 & 18.7 & 53 & 120 & 75 & 1.60 & 4.2 & 28.6 & 17.9 \\
\hline 6 & 108 & 68 & 1.5 & 3.9 & 27.7 & 17.4 & 54 & 120 & 77 & 1.56 & 3.9 & 30.8 & 19.8 \\
\hline 7 & 109 & 68 & 1.60 & 3.5 & 31.2 & 19.4 & 55 & 121 & 75 & 1.61 & 4.1 & 29.5 & 18.3 \\
\hline 8 & 110 & 69 & 1.59 & 3.6 & 30.6 & 19.2 & \multirow{2}{*}{\multicolumn{4}{|c|}{ Average $38-55: 1.576$}} & & & \\
\hline 9 & 110 & 69 & 1.59 & 3.7 & 29.7 & 18.7 & & & & & & 9.57 & 18.78 \\
\hline 10 & 110 & $\begin{array}{l}70 \\
71\end{array}$ & $\begin{array}{l}1.57 \\
1.56\end{array}$ & $\begin{array}{l}3.5 \\
4.0\end{array}$ & $\begin{array}{l}31.4 \\
27.8\end{array}$ & $\begin{array}{l}20.0 \\
17.8\end{array}$ & a & 122 & 77 & 1.59 & 4.0 & 30.5 & 19.3 \\
\hline 12 & 112 & 71 & 1.5 & 3. & 31.1 & 19.7 & J & 122 & 78 & 1.56 & 4.1 & 29.8 & 19.0 \\
\hline 13 & 112 & 72 & 1.5 & 4 & 5.5 & 16.4 & 58 & 122 & 78 & 1.56 & 4.0 & 30.5 & 19.5 \\
\hline 14 & 112 & 71 & 1.8 & 3. & 32.0 & 20.3 & (1) & 123 & 7 & 1.58 & 4.0 & 30.8 & 19.5 \\
\hline 15 & 113 & 72 & 1.5 & 4.5 & 26.3 & 16.8 & & 123 & 7 & 1.56 & & 27.4 & 17.6 \\
\hline 16 & 113 & 72 & 1.5 & 4.4 & 25.7 & 16.4 & 61 & 123 & 78 & 1.58 & 4.2 & 29.3 & 18.6 \\
\hline 17 & 114 & 72 & 1.5 & 4.2 & 27.2 & 17.1 & & 123 & 7 & 1.58 & 4.1 & 30.0 & 19.0 \\
\hline 18 & 114 & 73 & 1.56 & 4.1 & 27.8 & 17.8 & & 123 & 7 & 6 & & 9.3 & 18.8 \\
\hline Av & ore & 1 & 4 & & 28.97 & 18.41 & 65 & 123 & 81 & 1.52 & 4.0 & 30.8 & 20.2 \\
\hline & & & & & & & & 124 & 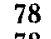 & 1.59 & & 31.0 & 19.5 \\
\hline 19 & 114 & 72 & 1.58 & 3.7 & 30.8 & 19.5 & 67 & 124 & 78 & 1.59 & 3.7 & 33.5 & 21.1 \\
\hline 20 & 1 & 74 & 1. & & 5 & 19.0 & 68 & 124 & 7 & 1. & 4 & 31.0 & 19.8 \\
\hline 21 & 11 & 74 & 1.5 & 3. & 1.1 & 20.0 & 69 & 124 & 79 & 1 & & 2.7 & 20.8 \\
\hline 22 & 115 & 73 & 1.5 & 4.0 & 8.8 & 18.2 & 70 & 124 & 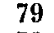 & 1. & & 28.2 & 18.0 \\
\hline 23 & 116 & 74 & 1.57 & 3.9 & 9.8 & 19.0 & 71 & 125 & 79 & 1. & 4 & 29.1 & 18.4 \\
\hline 24 & 116 & 74 & 1.57 & 3.9 & 9.8 & 19.0 & 72 & 125 & 79 & 1.5 & 3.8 & 32.9 & 20.8 \\
\hline 25 & 116 & 74 & 1.5 & 4. & 7.6 & 17.6 & 73 & 127 & 82 & 1.5 & 4.6 & 27.6 & 17.8 \\
\hline 26 & 11 & 74 & 1. & 3. & 9.8 & 19.0 & 74 & 134 & 84 & 1.60 & 4.4 & 30.4 & 19.1 \\
\hline 27 & 116 & 74 & & 3.8 & & 19.5 & \multirow{3}{*}{\multicolumn{4}{|c|}{$\begin{array}{ll}\text { Average 56_-74: } & 1.571 \\
\text { Total Average : } & 1.573\end{array}$}} & & & \\
\hline 28 & 116 & 74 & 1.57 & 3.9 & 29.8 & 19.0 & & & & & & 0.22 & 19.27 \\
\hline 29 & 116 & 73 & 1.59 & 3.8 & 30.5 & 19.2 & & & & & & & 1 \\
\hline 30 & 117 & 74 & 1.58 & 3.5 & 33.5 & 21.2 & \multirow{4}{*}{\multicolumn{7}{|c|}{ Herrings with 2 winter-rings. }} \\
\hline 31 & 117 & 74 & 1.58 & 3.9 & 30.0 & 19.0 & & & & & & & \\
\hline 32 & 117 & 74 & 1.58 & 3.7 & 31.6 & 20.0 & & & & & & & \\
\hline 33 & 117 & 75 & 1.56 & 3.9 & 30.0 & 19.2 & & & & & & & \\
\hline 34 & 117 & 75 & 1.56 & 4. & 28.6 & 18.3 & \multirow{2}{*}{ No. } & \multirow{2}{*}{ L } & & \multirow{2}{*}{$\frac{L_{2}}{T_{2}}=a_{2}$} & & L & $T$ \\
\hline $\mathbf{3 5}$ & 117 & 74 & 1. & 4 & $n$ & 18.1 & & & & & & $\overline{\mathbf{V}}$ & $\overline{\mathbf{V}}$ \\
\hline 36 & 117 & 75 & 1.5 & 4 & 28.6 & 18.3 & & & 0 & 1.5 & & & \\
\hline 3 & 1 & 75 & 1.6 & 4. & 29.3 & ? & & & & 1.5 & & $\begin{array}{l}27.4 \\
27.3\end{array}$ & \\
\hline tr & 10 & 27. & & & 29.91 & 2 & 3 & 148 & $g$ & 1.51 & & 27.4 & 18.2 \\
\hline 38 & & 7 & & & & & J & 15 & 9 & 1.5 & & $\mathbf{3}$ & 18.8 \\
\hline & & I & & & & & 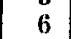 & 15 & 9 & 1.5 & & & \\
\hline 40 & & 74 & & & & & 7 & 15 & 9 & 1.5 & & 31.0 & 19 \\
\hline 41 & & 7 & & & & & 8 & 15 & 9 & 1.5 & & 26. & 17.4 \\
\hline 42 & & 7 & 1. & 4 & & & 0 & 15 & 9 & 1.5 & & 27.3 & 17.5 \\
\hline 43 & & 7 & 1. & 3. & & & 10 & 1 & 9 & 1.5 & & 28.0 & 18.0 \\
\hline 44 & & 7 & & 4.1 & 28 & & 11 & 155 & 10 & 1.5 & 6 & 27.7 & 17.9 \\
\hline 45 & & 76 & 1. & 4.0 & 29. & & 12 & 155 & 101 & 1.5 & 5 & 28.2 & 18.4 \\
\hline 4 & & 7 & 1.5 & 3. & 30 & 19.5 & 13 & 155 & 101 & 1.5 & 5.5 & 28.2 & 18.4 \\
\hline 4 & & 7 & 1.5 & 4.1 & & 18.5 & 14 & 157 & 102 & 1.54 & 5.4 & 29.1 & 18.9 \\
\hline 4 & & & 1.60 & 4.1 & 28.8 & 18.1 & 15 & 157 & 100 & 1.57 & 5.3 & 29.6 & 18.9 \\
\hline
\end{tabular}




\begin{tabular}{|c|c|c|c|c|c|c|c|c|c|c|c|c|c|}
\hline \multicolumn{7}{|c|}{ Herrings with 2 winter-rings. } & \multicolumn{7}{|c|}{ Herrings with 5 winter-rings. } \\
\hline No. & L & $\mathrm{T}$ & $\frac{\mathrm{L}_{3}}{\mathrm{~T}_{2}}=\mathrm{a}_{2}$ & V & $\frac{\mathrm{L}}{\overline{\mathrm{V}}}$ & $\frac{\mathrm{T}}{\mathrm{V}}$ & No. & L & $\mathrm{T}$ & $\frac{L_{5}}{T_{5}}=a_{5}$ & V & $\frac{\mathrm{L}}{\mathrm{V}}$ & $\frac{T}{V}$ \\
\hline 16 & 15 & 00 & U & 5.2 & 30.2 & 19.2 & 1 & 270 & 179 & 1.51 & 9.5 & 28.4 & 18.9 \\
\hline 17 & 10 & 101 & 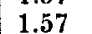 & $\because$ & 27.9 & 7.7 & 2 & 271 & 177 & 1.53 & 9.4 & 28.8 & 8.8 \\
\hline 18 & 159 & 102 & 1.56 & 5.6 & 28.4 & 18.2 & 3 & 273 & 176 & 1.55 & 9.5 & 28.7 & 18.5 \\
\hline \multicolumn{4}{|c|}{ Average $1-18: 1.557$} & & 28.50 & 18.29 & 5. & $\begin{array}{l}273 \\
274\end{array}$ & $\begin{array}{l}178 \\
180\end{array}$ & 1.53 & \begin{tabular}{|l}
10.3 \\
10.3
\end{tabular} & $\begin{array}{l}26.5 \\
26.6\end{array}$ & $\begin{array}{l}17.3 \\
17.5\end{array}$ \\
\hline & & & & & & & 6 & 277 & 185 & 1.50 & 9.5 & 29.2 & 19.5 \\
\hline 19 & 160 & 102 & 1.57 & 5.1 & 31.4 & 0.0 & 7 & 277 & 184 & 1.51 & 9.4 & 29.5 & 9.6 \\
\hline 20 & 161 & 104 & 1.55 & & 30.4 & 9.6 & 8 & 277 & 182 & 1.52 & 9.7 & 28.6 & 18.8 \\
\hline 21 & 162 & 104 & 1.56 & 5 & 28.4 & 18.3 & 9 & 278 & 181 & 1.54 & 10.4 & 26.7 & 17.4 \\
\hline 22 & 163 & 108 & 1.51 & $\mathbf{5}$ & 32.6 & 21.6 & 10 & 279 & 182 & 1.53 & 10.0 & 27.9 & 18.2 \\
\hline 23 & 163 & 106 & 1.54 & 5. & 29.1 & 18.9 & 11 & 279 & 183 & 1.52 & 9.6 & 29.1 & 9.1 \\
\hline 24 & 163 & 104 & 1.57 & 5 & 2 & 3.6 & 12 & 281 & 182 & 1.54 & 9.4 & 29.9 & 9.4 \\
\hline 25 & 164 & 107 & 1. & 5 & & .5 & 13 & 282 & 187 & 1.51 & 9.6 & 29.4 & 9.5 \\
\hline 26 & 165 & 105 & 1.5 & 5 & 2 & 7.8 & 14 & 282 & 186 & 1.52 & 9.9 & 28.5 & 8.8 \\
\hline 27 & 160 & 107 & 1.5 & 5 & 30 & 19.5 & 15 & 283 & 187 & 1.51 & 9.9 & 8.6 & 8.9 \\
\hline 28 & 166 & 107 & 1.55 & 5. & 29.6 & 19.1 & 16 & 283 & 186 & 1.52 & 9.4 & 30.1 & 9.8 \\
\hline 29 & 167 & 109 & 1.53 & 6.1 & 27.4 & 17.9 & 17 & 283 & 184 & 1.54 & 9.4 & 30.1 & 19.6 \\
\hline 30 & 170 & 108 & 1.57 & 5.4 & 31.5 & 20.0 & & & & & & & \\
\hline 31 & 171 & 111 & 1.54 & 5.8 & 29.5 & 19.2 & \multirow{2}{*}{\multicolumn{4}{|c|}{ Average $1-17: 1.523$}} & & 28.62 & 18.80 \\
\hline 32 & 172 & 111 & 1.55 & 5.8 & 29.7 & 19.2 & \multirow{16}{*}{$\begin{array}{l}18 \\
19 \\
20 \\
21 \\
22 \\
23 \\
24 \\
25 \\
26 \\
27 \\
28 \\
29 \\
30 \\
31 \\
32 \\
33\end{array}$} & & & & & & \\
\hline 33 & 172 & 110 & 1.56 & 6. & 28.4 & 18.3 & & 283 & 184 & 1.54 & 10.5 & 27.0 & 17.5 \\
\hline 34 & 173 & 110 & 1.57 & 5.8 & 29.3 & 18.6 & & 284 & 188 & 1.51 & 9.6 & 9.6 & 9.6 \\
\hline 35 & 181 & 115 & 1.57 & 6.1 & 29.7 & 18.9 & & 284 & 187 & 1.52 & 9.6 & 29.6 & 9.5 \\
\hline 36 & 183 & 116 & 1.58 & 6.7 & 27.3 & 17.3 & & 285 & 193 & 1.48 & 10.3 & 27.7 & 18.7 \\
\hline \multirow{3}{*}{\multicolumn{3}{|c|}{$\begin{array}{l}\text { Average } 19-36: \\
\text { Total average: }\end{array}$}} & 554 & & 2052 & 19 & & 287 & 191 & 1.50 & 10.3 & 27.9 & 18.5 \\
\hline & & & & & & 19.0 & & 288 & 189 & 1.52 & 10.2 & 28.3 & 18.5 \\
\hline & & & & & & & & 289 & 187 & 1.5 & 10.4 & 27.8 & $18 . \theta$ \\
\hline \multirow{3}{*}{\multicolumn{7}{|c|}{ Herrings with 3 winter-rings. }} & & 289 & 189 & 1.53 & 9.8 & 29.5 & 9.3 \\
\hline & & & & & & & & 290 & 190 & 1.53 & 9.8 & 29.6 & 19.4 \\
\hline & & & & & & & & 292 & 194 & 1.51 & 9.9 & 29.5 & 9.6 \\
\hline & I & $\mathbf{T}$ & & $\mathbf{v}$ & L & $\mathrm{T}$ & & $\begin{array}{l}294 \\
294\end{array}$ & $\begin{array}{l}196 \\
195\end{array}$ & & $\begin{array}{r}9.9 \\
10.8\end{array}$ & $\begin{array}{l}29.7 \\
27.2\end{array}$ & $\begin{array}{l}19.8 \\
18.1\end{array}$ \\
\hline $\mathrm{N}$ & L & T & & V & $\overline{\mathrm{V}}$ & $\overline{\mathrm{V}}$ & & 295 & 196 & 1.51 & 10.4 & 28.4 & 18.8 \\
\hline & & & & & & & & 296 & 198 & 1.49 & $\mid \begin{array}{l}10.2 \\
\end{array}$ & 29.0 & 19. \\
\hline 1 & 222 & 145 & 1.53 & 8.3 & 26.8 & 17.5 & & 296 & 196 & 1.5 & 10.3 & 28.7 & 19.0 \\
\hline 2 & 227 & 146 & 1.55 & & 2 & .6 & & 297 & 194 & 1.53 & 9.8 & 30.3 & 19.8 \\
\hline \multirow{2}{*}{\multicolumn{4}{|c|}{ Average: 1.54}} & & 27.10 & 17.55 & \multirow{2}{*}{\multicolumn{4}{|c|}{$\begin{array}{ll}\text { Average } 18-33: & 1.515 \\
\text { Total average : } & 1.519\end{array}$}} & & 74 & 18.96 \\
\hline & & & & & & & & & & & & & \\
\hline \multicolumn{7}{|c|}{ Herrings with 4 winter-rings. } & \multirow{2}{*}{\multicolumn{7}{|c|}{ Herrings with 6 winter-rings. }} \\
\hline & & & & & & & & & & & & & \\
\hline No. & L & $\mathrm{T}$ & & V & V & $\overline{\mathrm{V}}$ & No. & $\mathrm{L}$ & $\mathrm{T}$ & $\frac{\mathrm{L}_{\mathrm{t}}}{\mathrm{T}}=\mathrm{a}_{\mathrm{B}}$ & V & $\frac{\mathrm{L}}{\mathrm{V}}$ & $\frac{T}{V}$ \\
\hline 1 & 236 & 153 & 1.54 & 8.8 & 25.7 & 17.4 & & & & & & & \\
\hline 2 & 239 & & 1. & & & & 1 & & & & & & \\
\hline 3 & 251 & & & 9.1 & 27 & & 2 & & & & & & \\
\hline 4 & & & & 9.0 & & & 4 & & & & $9 ?$ & & \\
\hline 5 & 259 & & & 9.3 & & 18 & 4 & $\begin{array}{l}2,99 \\
260\end{array}$ & $\begin{array}{l}160 \\
169\end{array}$ & 1 & 9.2 & & 8.5 \\
\hline 6 & & & & & & & a & $\begin{array}{l}200 \\
260\end{array}$ & 17 & 1. & $\begin{array}{l}9.0 \\
9.4\end{array}$ & 7 & 189 \\
\hline 7 & 26 & 17 & 1. & 10 & 9 & & 0 & $\begin{array}{l}200 \\
261\end{array}$ & 169 & & 9.1 & 7 & $\begin{array}{l}18.2 \\
18.6\end{array}$ \\
\hline 8 & 264 & 1 & 1. & & 2 & & 8 & 261 & 17 & & 9.4 & 27 & 18.1 \\
\hline 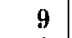 & 268 & 17 & & & 28. & & 9 & 262 & 17 & 1. & 9.6 & 2 & 17.7 \\
\hline 10 & 283 & 19 & & .9 & 28 & & 10 & 264 & 17 & & 9 & 7 & 17.2 \\
\hline 1 . & 28 & 18 & & & & & 11 & 264 & & 1. & 9.6 & & 18.0 \\
\hline \multirow{2}{*}{\multicolumn{3}{|c|}{ Average: }} & 16 & & 27.37 & 8.10 & 12 & 26 & 17 & 1.5 & 9.7 & 27.3 & 17.8 \\
\hline & & & & & & & & 266 & 173 & 1.5 & 9.7 & 27.4 & 17.8 \\
\hline
\end{tabular}




\begin{tabular}{|c|c|c|c|c|c|c|c|c|c|c|c|c|c|}
\hline \multicolumn{7}{|c|}{ Herrings with 6 winter-rings. } & \multicolumn{7}{|c|}{ Herrings with 6 winter-rings. } \\
\hline No. & L & $\mathbf{T}$ & $\frac{L_{b}}{T_{n}}=a_{b}$ & $\mathbf{V}$ & $\frac{\mathrm{L}}{\mathrm{V}}$ & $\frac{T}{V}$ & No. & L & $\mathbf{T}$ & $\frac{L_{6}}{T_{6}}=a_{6}$ & $\mathbf{V}$ & $\frac{L}{\bar{V}}$ & $\frac{T}{V}$ \\
\hline 14 & 266 & 173 & 1.54 & 9.7 & 27.4 & 17.8 & 70 & 278 & 182 & 1.53 & 9.7 & 28.7 & 18.8 \\
\hline 15 & 266 & 175 & 1.52 & 9.5 & 28.0 & 18.4 & 71 & 278 & 182 & 1.53 & 10.5 & 26.5 & 17.3 \\
\hline 16 & 266 & 178 & 1.49 & 9.5 & 28.0 & 18.7 & 72 & 278 & 182 & 1.53 & 9.9 & 28.1 & 18.4 \\
\hline 17 & 266 & 175 & 1.52 & 9.0 & 29.6 & 19.5 & 73 & 278 & 183 & 1.52 & 10.4 & 26.7 & 17.6 \\
\hline 18 & 267 & 178 & 1.50 & 9.7 & 27.5 & 18.4 & 74 & 278 & 182 & 1.53 & 10.1 & 27.5 & 18.0 \\
\hline 19 & 267 & 175 & 1.53 & 10.0 & 26.7 & 17.5 & 75 & 279 & 183 & 1.52 & 9.8 & 28.5 & 18.7 \\
\hline 20 & 267 & 174 & 1.53 & 9.4 & 28.4 & 18.5 & 76 & 279 & 182 & 1.53 & 9.7 & 28.8 & 18.8 \\
\hline 21 & 267 & 175 & 1.53 & 9.6 & 27.8 & 18.2 & 77 & 279 & 183 & 1.52 & 10.0 & 27.9 & 18.3 \\
\hline 22 & 268 & 172 & 1.56 & 8.6 & 31.2 & 20.0 & 78 & 279 & 183 & 1.52 & 9.0 & 31.0 & 20.3 \\
\hline 23 & 268 & 177 & 1.51 & 8.9 & 30.2 & 19.9 & 79 & 279 & 186 & 1.50 & 10.1 & 27.6 & 18.4 \\
\hline 24 & 269 & 144 & 1.55 & 9.1 & 29.6 & 19.1 & 80 & 279 & 183 & 1.52 & 10.1 & 27.6 & 18.1 \\
\hline 25 & 270 & 174 & 1.55 & 9.5 & 28.4 & 18.3 & 81 & 279 & 183 & 1.52 & 9.6 & 29.1 & 19.1 \\
\hline 26 & 270 & 177 & 1.52 & 9.9 & 27.3 & 17.9 & 82 & 280 & 184 & 1.52 & 10.1 & 27.7 & 18.2 \\
\hline 27 & 270 & 177 & 1.53 & 9.2 & 29.4 & 19.3 & 83 & 280 & 186 & 1.50 & 10.8 & 25.9 & 17.2 \\
\hline 28 & 270 & 177 & 1.53 & 9.4 & 28.7 & 18.9 & 84 & 280 & 182 & 1.54 & 10.5 & 26.7 & 17.3 \\
\hline 29 & 270 & 179 & 1.51 & 10.4 & 26.0 & 17.2 & 85 & 280 & 184 & 1.52 & 9.5 & 29.5 & 19.4 \\
\hline 30 & 270 & 172 & 1.57 & 9.6 & 28.2 & 17.9 & 86 & 280 & 182 & 1.54 & 9.5 & 29.5 & 19.2 \\
\hline 31 & 272 & 178 & 1.53 & 9.5 & 28.6 & 18.7 & 87 & 281 & 185 & 1.52 & 10.1 & 27.8 & 18.3 \\
\hline 32 & 272 & 178 & 1.53 & 10.5 & 25.9 & 17.0 & 88 & 281 & 187 & 1.50 & 9.6 & 29.3 & 19.5 \\
\hline $\mathbf{3 3}$ & 272 & 176 & 1.54 & 9.5 & 28.6 & 18.5 & 89 & 281 & 190 & 1.48 & 10.1 & 27.8 & 18.8 \\
\hline 34 & 272 & 176 & 1.54 & 9.9 & 27.5 & 17.8 & 90 & 282 & 185 & 1.52 & 9.6 & 29.4 & 19.3 \\
\hline $\mathbf{3 5}$ & 272 & 180 & 1.51 & 9.7 & 28.0 & 18.6 & 91 & 282 & 189 & 1.49 & 9.4 & 30.0 & 20.1 \\
\hline 36 & 273 & 179 & 1.53 & 10.0 & 27.3 & 17.9 & 92 & 282 & 184 & 1.53 & 9.8 & 28.8 & 18.7 \\
\hline 37 & 273 & 176 & 1.55 & 9.7 & 28.1 & 18.2 & 93 & 282 & 188 & 1.50 & 9.8 & 28.8 & 19.2 \\
\hline 38 & 273 & 179 & 1.53 & 9.2 & 29.7 & 19.5 & 94 & 282 & 186 & 1.52 & 10.6 & 26.6 & 17.6 \\
\hline 39 & 273 & 181 & 1.51 & 9.9 & 27.6 & 18.3 & 95 & 283 & 186 & 1.52 & 9.9 & 28.6 & 18.8 \\
\hline 40 & 273 & 182 & 1.50 & 9.9 & 27.6 & 18.4 & 96 & 283 & 183 & 1.55 & 9.8 & 28.9 & 18.8 \\
\hline 41 & 273 & 180 & 1.52 & 9.7 & 282 & 18.6 & 97 & 283 & 186 & 1.52 & 9.4 & 30.1 & 19.8 \\
\hline 42 & 274 & 179 & 1.53 & 9.5 & 28.9 & 18.9 & 98 & 284 & 187 & 1.52 & 9.1 & 31.2 & 20.4 \\
\hline 43 & 274 & 178 & 1.54 & 9.5 & 28.9 & 18.8 & 99 & 284 & 187 & 1.52 & 10.5 & 27.0 & 17.8 \\
\hline 44 & 274 & 181 & 1.51 & 9.6 & 28.6 & 18.9 & 100 & 284 & 183 & 1.55 & 9.4 & 30.2 & 19.5 \\
\hline 45 & 274 & 187 & 1.47 & 9.5 & 28.9 & 19.7 & 101 & 284 & 187 & 1.52 & 10.9 & 26.1 & 17,2 \\
\hline 46 & 274 & 179 & 1.53 & 9.9 & 27.7 & 18.1 & 102 & 284 & 183 & 1.55 & 10.8 & 26.3 & 17.4 \\
\hline 47 & 274 & 179 & 1.53 & 8.9 & 30.8 & 20.1 & 103 & 284 & 186 & 1.53 & 9.9 & 28.7 & 18.8 \\
\hline 48 & 275 & 179 & 1.54 & 10.3 & 26.7 & 17.4 & 104 & 284 & 187 & 1.52 & 10.3 & 27.6 & 18.2 \\
\hline 49 & 275 & 184 & 1.49 & 9.6 & 28.6 & 19.2 & 105 & 285 & 189 & 1.51 & 9.9 & 28.8 & 19.1 \\
\hline 50 & 275 & 177 & 1.55 & 10.6 & 27.0 & 16.7 & 106 & 285 & 186 & 1.53 & 10.2 & 28.0 & 18.2 \\
\hline 51 & 275 & 180 & 1.53 & 9.5 & 28.0 & 19.0 & 107 & 285 & 191 & 1.49 & 10.1 & 28.1 & 18.9 \\
\hline 52 & 275 & 179 & 1.54 & 10.1 & 27.2 & 17.7 & 108 & 285 & 188 & 1.52 & 9.7 & 29.4 & 19.4 \\
\hline 53 & 275 & 181 & 1.52 & 9.9 & 27.8 & 18.3 & 109 & 285 & 187 & 1.52 & 11.0 & 25.9 & 17.0 \\
\hline \multirow[t]{2}{*}{54} & 275 & 178 & 1.54 & 9.7 & 28.3 & 18.4 & & & & & & & \\
\hline & & & & & & & \multicolumn{3}{|c|}{ Average 55-109: } & 1.518 & & 28.05 & 18.59 \\
\hline \multicolumn{4}{|c|}{ Average $1-54: 1.528$} & & 7.78 & 18.24 & & & & & & & \\
\hline & & & & & & & & $\begin{array}{l}285 \\
085\end{array}$ & 191 & 1.49 & 10.3 & 27.7 & 18.5 \\
\hline $\begin{array}{l}55 \\
56\end{array}$ & $\begin{array}{l}2 / 3 \\
275\end{array}$ & $\begin{array}{l}180 \\
182\end{array}$ & 1. & $\begin{array}{r}9.2 \\
11.0\end{array}$ & 25.0 & 16.5 & 1 & $\begin{array}{l}285 \\
285\end{array}$ & $\begin{array}{l}188 \\
189\end{array}$ & $\begin{array}{l}1.52 \\
1.51\end{array}$ & $\begin{array}{l}10.1 \\
9.7\end{array}$ & $\begin{array}{l}28.2 \\
29.4\end{array}$ & $\begin{array}{l}18.6 \\
19.5\end{array}$ \\
\hline 57 & 276 & 184 & 1.50 & 9.5 & 29.1 & 19.4 & & 285 & 189 & 1.51 & 10.0 & 28.5 & 18.9 \\
\hline 58 & 276 & 183 & 1.51 & 9.8 & 28.2 & 18.7 & & 285 & 190 & 1.50 & 10.4 & 27.4 & 18.3 \\
\hline 59 & 276 & 184 & 1.50 & 10.3 & 26.8 & 17.9 & & 285 & 189 & 1.51 & 9.9 & 28.8 & 19.1 \\
\hline 60 & 276 & 181 & 1.47 & 10.1 & 27.3 & 17.9 & & 285 & 189 & 1.51 & 9.7 & 29.4 & 19.5 \\
\hline 61 & 276 & 183 & 1.51 & 9.0 & 30.7 & 20.3 & 117 & 285 & 190 & 1.50 & 10.5 & 27.1 & 18.1 \\
\hline 62 & 277 & 183 & 1.51 & 10.1 & 27.4 & 18.1 & & 286 & 189 & 1.51 & 10.0 & 28.6 & 18.9 \\
\hline 63 & 277 & 181 & 1.53 & 9.5 & \begin{tabular}{|l|}
29.2 \\
\end{tabular} & 19.1 & & 286 & 189 & 1.51 & 10.5 & 27.2 & 18.0 \\
\hline 64 & 277 & 186 & 1.49 & 9.6 & 28.9 & 19.4 & & 286 & 185 & 1.55 & 10.0 & 28.6 & 18.5 \\
\hline 65 & 277 & 182 & 1.52 & 10.5 & 26.4 & 17.3 & 1 & 286 & 186 & 1.54 & 9.8 & 29.2 & 19.0 \\
\hline 66 & 278 & 183 & 1.52 & 9.7 & 28.7 & 18.9 & 122 & 286 & 191 & 1.50 & 9.9 & 28.9 & 19.3 \\
\hline 67 & 278 & 183 & 1.52 & 9.6 & 29.0 & 19.1 & & 286 & 188 & 1.52 & 9.9 & 28.9 & 19.0 \\
\hline 68 & 278 & 183 & 1.52 & 10.4 & 26.7 & 17.6 & & 286 & 191 & 1.50 & 10.1 & 28.3 & 18.9 \\
\hline 69 & 278 & 182 & 1.53 & 9.7 & 28.7 & 18.8 & 25 & 287 & 189 & 1.52 & 9.8 & 29.3 & 19.3 \\
\hline
\end{tabular}




\begin{tabular}{|c|c|c|c|c|c|c|c|c|c|c|c|c|c|}
\hline \multicolumn{7}{|c|}{ Herrings with 6 winter-rings. } & \multicolumn{7}{|c|}{ Herrings with 6 winter-rings. } \\
\hline No. & L & $\mathrm{T}$ & $\frac{L_{h}}{T_{R}}=a_{h}$ & V & $\frac{\mathrm{L}}{\mathrm{V}}$ & $\frac{\mathrm{T}}{\mathrm{V}}$ & No: & I. & $\mathbf{T}$ & $\begin{array}{l}\mathrm{L}_{\mathrm{b}}=\mathrm{a}_{\mathrm{B}} \\
\mathrm{T}_{\mathrm{A}}\end{array}$ & V & $\overline{\mathbf{L}}$ & $\frac{T}{V}$ \\
\hline 126 & 287 & 186 & 1.54 & 10.2 & 28.1 & 18.2 & 182 & 294 & 196 & 1.50 & 9.8 & 30.0 & 19.8 \\
\hline 127 & 287 & 189 & 1.52 & $\mid 11.2$ & 25.6 & 16.9 & 183 & 294 & 195 & 1.51 & 10.4 & 28.3 & 18.7 \\
\hline 128 & 287 & 189 & 1.52 & 10.6 & 27.1 & 17.8 & 184 & 295 & 197 & 1.50 & 10.6 & 27.8 & 18.6 \\
\hline 129 & 287 & 191 & 1.50 & 10.3 & 27.9 & 18.5 & 185 & 295 & 199 & 1.48 & 10.4 & 28.4 & 19.1 \\
\hline 130 & 287 & 191 & 1.50 & 9.6 & 29.9 & 19,9 & 186 & 295 & 195 & 1.51 & 9.9 & 29.8 & 19.7 \\
\hline 131 & 287 & 190 & 1.51 & 9.7 & 29.6 & 19.6 & 187 & 295 & 194 & 1.52 & 10.3 & 28.6 & 18.8 \\
\hline 132 & 287 & 187 & 1.53 & 10.5 & 27.4 & 17.8 & 188 & 295 & 192 & 1.54 & 10.2 & 28.9 & 18.8 \\
\hline 133 & 287 & 190 & 1.51 & 9.9 & 29.0 & 19.2 & 189 & 295 & 193 & 1.53 & 10.3 & 28.6 & 18.7 \\
\hline 134 & 287 & 188 & 1.53 & 9.7 & 29.6 & 19.4 & 190 & 295 & 193 & 1.53 & 9.9 & 29.8 & 19.5 \\
\hline 135 & 287 & 191 & 1.50 & 9.3 & 30.9 & 20.5 & 191 & 295 & 193 & 1.53 & 10.3 & 28.6 & 18.7 \\
\hline 136 & 287 & 192 & 1.49 & 10.1 & 28.4 & 19.0 & 192 & 295 & 194 & 1.52 & 10.2 & 28.9 & 19.0 \\
\hline 137 & 287 & 188 & 1.53 & 9.8 & 29.3 & 19.2 & 193 & 295 & 193 & 1.53 & 10.9 & 27.1 & 17.7 \\
\hline 138 & 287 & 190 & 1.51 & 10.9 & 26.3 & 17.4 & 194 & 296 & 196 & 1.51 & 10.6 & 27.9 & 18.5 \\
\hline 139 & 287 & 188 & 1.53 & 10.4 & 27.6 & 18.1 & 195 & 296 & 197 & 1.50 & 10.1 & 29.3 & 19.5 \\
\hline 140 & 287 & 190 & 1.51 & 9.5 & 30.2 & 20.0 & 196 & 296 & 196 & 1.51 & 11.6 & 25.5 & 16.9 \\
\hline 141 & 287 & 191 & 1.50 & 9.5 & 30.2 & 20.1 & 197 & 296 & 196 & 1.51 & 10.7 & 27.6 & 18.3 \\
\hline 142 & 288 & 189 & 1.52 & 10.6 & 27.2 & 17.8 & 198 & 297 & 197 & 1.51 & 10.3 & 28.8 & 19.1 \\
\hline 143 & 288 & 190 & 1.52 & 10.6 & 27.2 & 17.9 & 199 & 297 & 198 & 1.50 & 10.8 & 27.5 & 18.3 \\
\hline 144 & 288 & 188 & 1.53 & 10.3 & 27.9 & 18.3 & 200 & 298 & 196 & 1.52 & 10.3 & 29.0 & 19.0 \\
\hline 145 & 288 & 191 & 1.51 & 10.2 & 28.2 & 18.7 & 201 & 298 & 197 & 1.51 & 9.8 & 30.4 & 20.1 \\
\hline 146 & 288 & 189 & 1.52 & 10.2 & 28.2 & 18.5 & 202 & 299 & 197 & 1.52 & 9.5 & 31.5 & 20.7 \\
\hline 147 & 288 & 191 & 1.51 & 10.4 & 27.7 & 18.4 & 203 & 299 & 196 & 1.53 & 10.6 & 28.2 & 18.5 \\
\hline 148 & 288 & 188 & 1.53 & 9.8 & 29.4 & 19.2 & 204 & 299 & 198 & 1.51 & 10.1 & 29.6 & 19.6 \\
\hline 149 & 288 & 189 & 1.52 & 9.8 & 29.4 & 19.3 & 205 & 299 & 196 & 1.53 & 10.7 & 28.0 & 18.3 \\
\hline 150 & 288 & 189 & 1.52 & 9.2 & 31.3 & 20.6 & 206 & 299 & 203 & 1.47 & 10.0 & 29.9 & 20.3 \\
\hline 151 & 288 & 188 & 1.53 & 10.8 & 26.7 & 17.4 & 207 & 300 & 195 & 1.54 & 10.2 & 29.4 & 19.1 \\
\hline 152 & 288 & 192 & 1.50 & 10.3 & 28.0 & 18.6 & 208 & 300 & 200 & 1.50 & 10.3 & 29.1 & 19.4 \\
\hline 153 & 288 & 192 & 1.50 & 9.2 & 31.3 & 20.9 & 209 & 300 & 201 & 1.49 & 9.4 & 31.9 & 21.4 \\
\hline 154 & 289 & 193 & 1.50 & 10.1 & 286 & 19.1 & 210 & 302 & 198 & 1.53 & 10.7 & 28.2 & 18.5 \\
\hline 155 & 289 & 190 & 1.52 & 9.8 & 29.5 & 19.4 & 211 & 302 & 199 & 1.52 & 10.3 & 29.3 & 19.3 \\
\hline 156 & 289 & 189 & 1.53 & 9.2 & 31.4 & 20.6 & 212 & 302 & 202 & 1.50 & 10.6 & 28.5 & 19.1 \\
\hline 157 & 289 & 190 & 1.52 & 10.2 & 28.4 & 18.6 & 213 & 302 & 200 & 1.51 & 10.0 & 30.2 & 20.0 \\
\hline 158 & 289 & 192 & 1.51 & 10.2 & 28.4 & 18.8 & 4 & 302 & 199 & 1.52 & 10.8 & 28.0 & 18.4 \\
\hline 159 & 290 & 186 & 1.56 & 10.2 & 28.4 & 18.2 & 215 & 304 & 206 & 1.48 & 11.4 & 26.7 & 18.1 \\
\hline 160 & 290 & 191 & 1.52 & 10.2 & 28.4 & 18.7 & 216 & 304 & 199 & 1.53 & 10.2 & 29.8 & 19.5 \\
\hline 161 & 290 & 188 & 1.54 & 10.6 & 27.4 & 17.7 & 217 & 305 & 204 & 1.49 & 10.4 & 29.3 & 19.6 \\
\hline 162 & 291 & 190 & 1.53 & 10.6 & 27.5 & 17.9 & 218 & 310 & 208 & 1.49 & 11.2 & 27.7 & 18.6 \\
\hline 163 & 291 & 191 & 1.52 & 10.7 & 27.2 & 17.8 & & & & & & & \\
\hline \multicolumn{4}{|c|}{ Average $110.163: 1.516$} & & 8 & 8.8 & \multirow{2}{*}{\multicolumn{4}{|c|}{$\begin{array}{ll}\text { Average } 164-218: & 1.513 \\
\text { Total average: } & 1.519 \\
\end{array}$}} & & & 861 \\
\hline & & & & & & & \multirow{4}{*}{\multicolumn{7}{|c|}{ Herrings with 7 winter-rings. }} \\
\hline 164 & 292 & 194 & 1.50 & 10.2 & 28.6 & 19.0 & & & & & & & \\
\hline 165 & 292 & 190 & 1.54 & 10.3 & 28.4 & 18.4 & & & & & & & \\
\hline 166 & 292 & 194 & 1.50 & 10.4 & 28.1 & 18.7 & & & & & & & \\
\hline 167 & 292 & 188 & 1.55 & 10.3 & 28.4 & 18.2 & \multirow{3}{*}{ No. } & \multirow{2}{*}{ L } & \multirow{2}{*}{$\mathrm{T}$} & \multirow{2}{*}{$\frac{L_{7}}{T_{7}}=a_{7}$} & \multirow[b]{2}{*}{$v$} & I. & $\mathbf{T}$ \\
\hline 168 & 292 & 193 & 1.51 & 10.8 & 27.1 & 17.9 & & & & & & $\overline{\mathbf{v}}$ & $\overline{\mathbf{v}}$ \\
\hline 169 & 292 & 192 & 1.52 & 10.2 & 28.6 & 18.8 & & & & & & & \\
\hline 170 & 292 & 193 & 1.51 & 9.6 & 30.4 & 20.1 & 1 & 263 & 170 & 1.55 & 9.9 & 26.6 & 17. \\
\hline 171 & 293 & 193 & 1.52 & 10.3 & 28.4 & 18.7 & 2 & 281 & 185 & 1.52 & 9.5 & 29.6 & 19.5 \\
\hline 172 & 293 & 193 & 1.52 & 10.2 & 28.7 & 18.9 & 3 & 283 & 185 & 1.53 & 10.3 & 27.5 & 18.0 \\
\hline 173 & 293 & 193 & 1.52 & 10.6 & 27.6 & 18.2 & 4 & 287 & 193 & 1.49 & 10.4 & 27.6 & 18.5 \\
\hline 174 & 293 & 195 & 1.50 & 10.1 & 29.0 & 19.3 & 5 & 289 & 193 & 1.49 & 10.2 & 28.4 & 18.9 \\
\hline 175 & 293 & 194 & 1.51 & 9.7 & 30.2 & 20.0 & 6 & 289 & 190 & 1.52 & 10.8 & 27.7 & 17.6 \\
\hline 176 & 293 & 192 & 1.53 & 10.7 & 27.4 & 17.9 & 7 & 291 & 196 & 1.48 & 10.2 & 28.5 & 19.2 \\
\hline 177 & 293 & 192 & 1.53 & 10.5 & 27.9 & 18.3 & 8 & 293 & 196 & 1.49 & 10.8 & 27.1 & 18.2 \\
\hline 178 & 293 & 191 & 1.53 & 10.8 & 27.2 & 17.7 & 9 & 294 & 192 & 1.53 & 10.7 & 27.5 & 17.9 \\
\hline 179 & 294 & 196 & 1.50 & 9.8 & 30.0 & 20.0 & 10 & 294 & 193 & 1.52 & 10.4 & 28.3 & 18.6 \\
\hline 180 & 294 & 198 & 1.48 & 9.9 & 29.7 & 20.0 & 11 & 294 & 193 & 1.52 & 9.9 & 29.5 & 19.5 \\
\hline 181 & 294 & 193 & 1.52 & 10.5 & 28.0 & 18.4 & 12 & 296 & 197 & 1.50 & 9.7 & 30.5 & 20.3 \\
\hline
\end{tabular}




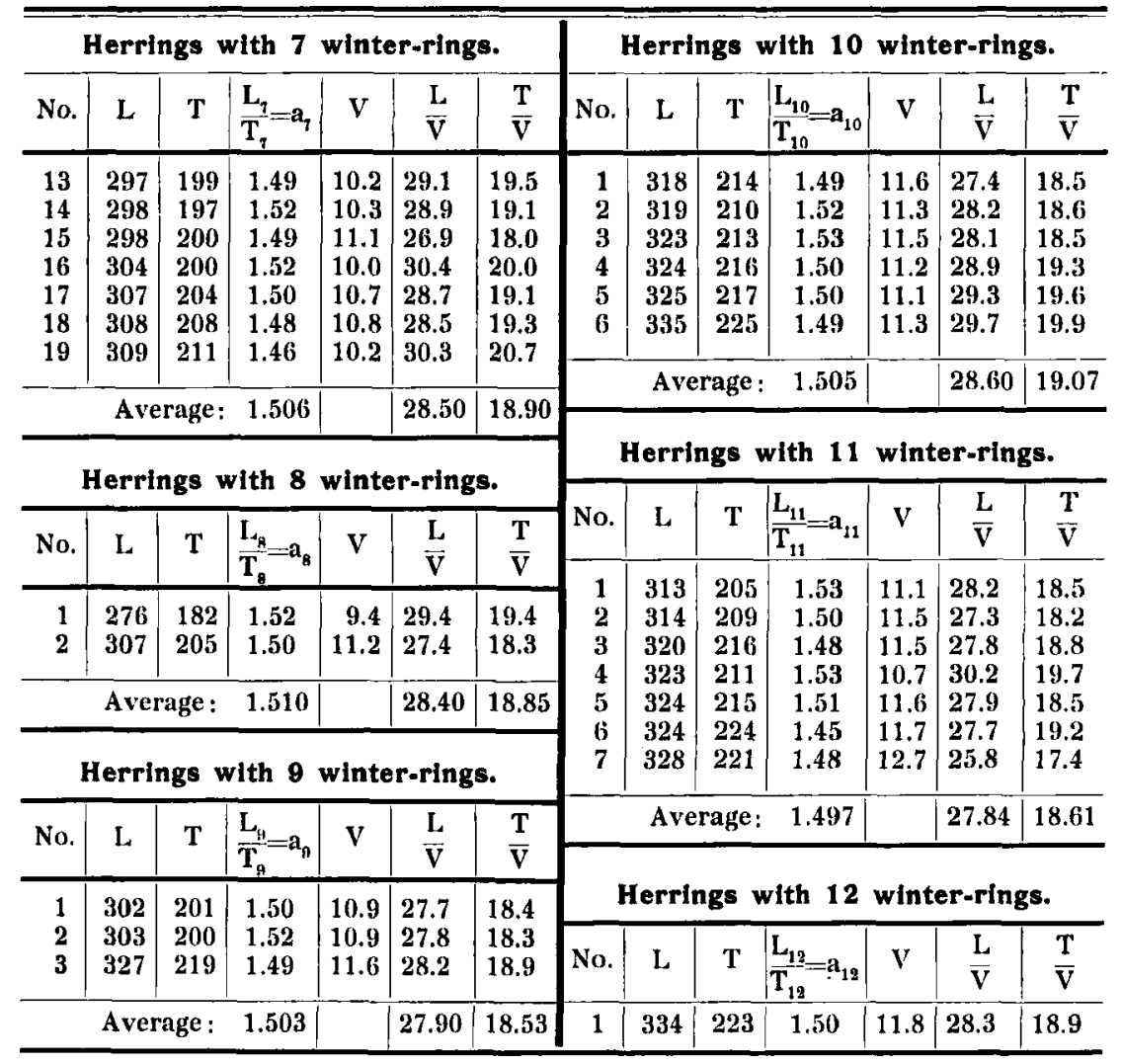


TABLE II.

Measurements of scales from a Norweglan spring-herring 6 years old, total-length $L=291 \mathrm{~mm}$., based on the formulae $1_{1}=L \cdot \frac{v_{1}}{V}$,

$$
\mathrm{l}_{2}=L: \frac{\mathrm{v}_{2}}{\mathrm{~V}} \ldots, \mathrm{t}_{1}=\mathrm{l}_{1}-0=\mathbf{1}_{1}, \mathrm{t}_{2}=\mathrm{l}_{2}-\mathrm{l}_{1} \ldots
$$

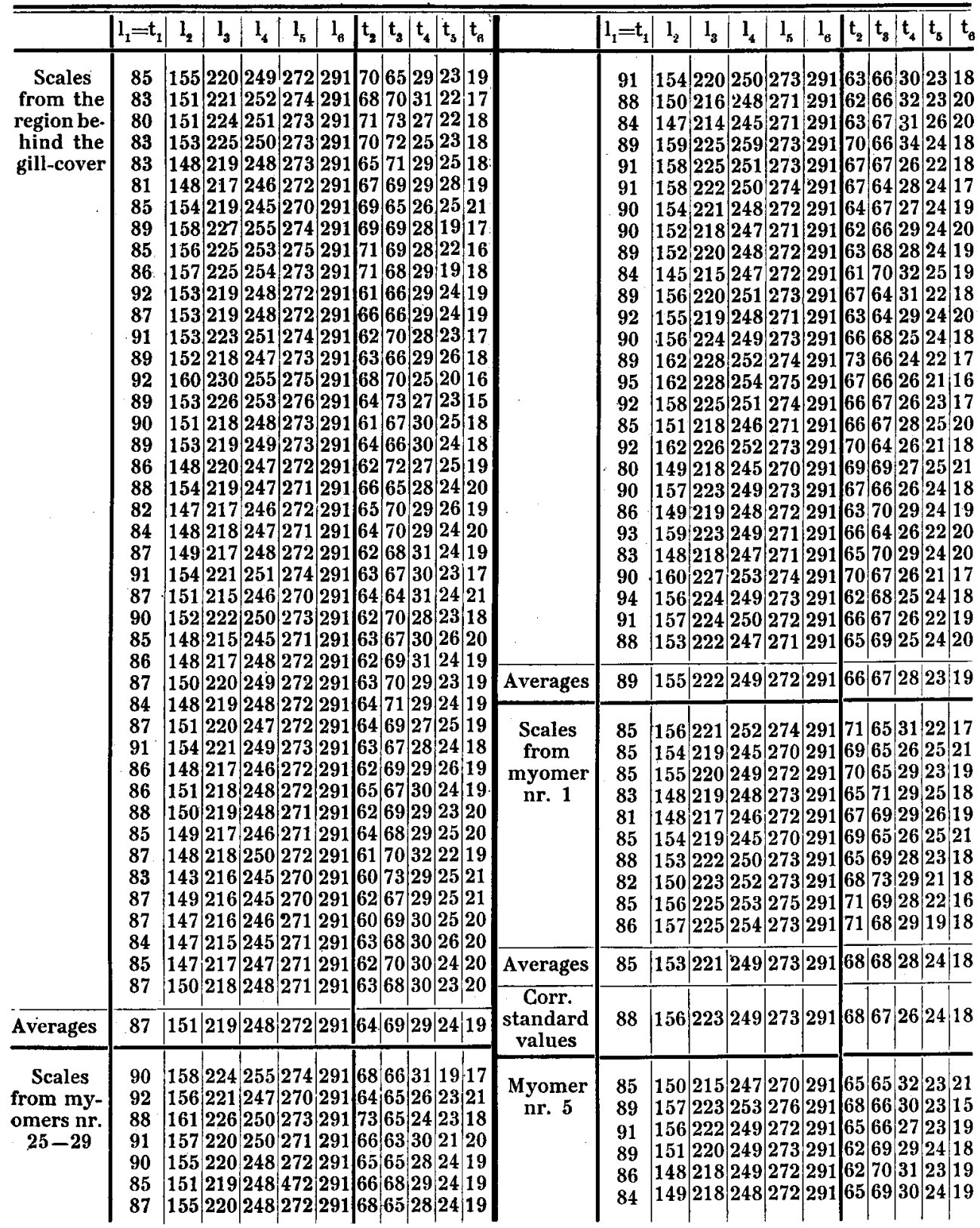




\begin{tabular}{|c|c|c|c|c|c|c|c|c|c|c|c|c|c|c|c|c|c|c|c|c|c|}
\hline & $l_{1}=t_{1}$ & $I_{2}$ & $\mathbf{l}_{\mathbf{3}}$ & 14 & $l_{5}$ & 16 & $\left|\mathbf{t}_{2}\right|$ & $t_{3} \mid t$ & \begin{tabular}{|l|l|}
$\mathrm{t}_{4}$ & $\mathrm{t}_{\mathrm{s}}$ \\
\end{tabular} & $t_{b}$ & & $l_{1}=t_{1}$ & $l_{2}$ & $l_{3}$ & $\mathrm{I}_{4}$ & $1_{6}$ & $1_{\theta}$ & $t_{2}$ & \begin{tabular}{|l|l|}
$t_{3}$ & $t_{4}$ \\
\end{tabular} & $\mid t_{b}$ & $t_{s}$ \\
\hline & $\begin{array}{l}83 \\
87\end{array}$ & $\begin{array}{l}148 \\
160\end{array}$ & $\begin{array}{l}218 \\
231\end{array} \mid$ & $\left|\begin{array}{l}248 \\
257\end{array}\right|$ & $\left|\begin{array}{l}273 \\
276\end{array}\right|$ & $\begin{array}{l}291 \\
291\end{array}$ & $\begin{array}{l}65 \\
73\end{array}$ & $\left|\begin{array}{l}70 \\
71\end{array}\right|$ & \begin{tabular}{|l|l|}
30 & 25 \\
26 & 19
\end{tabular} & \begin{tabular}{l|l}
5 & 18 \\
9 & 15
\end{tabular} & & 90 & $\begin{array}{l}155 \\
151\end{array}$ & $\begin{array}{l}220 \\
219 \\
000\end{array}$ & 248 & 272 & 291 & $65 \mid 6$ & \begin{tabular}{l|l|}
65 & 28 \\
68 & 29 \\
\end{tabular} & & 19 \\
\hline Averages & 87 & 152 & $221 \mid$ & 250 & 273 & 291 & 65 & $\left.69\right|^{2}$ & \begin{tabular}{|l|l|}
29 & 23 \\
\end{tabular} & 318 & & $\begin{array}{l}01 \\
91\end{array}$ & $\mid \begin{array}{l}150 \\
154\end{array}$ & 220 & 248 & $\left|\begin{array}{l}272 \\
273\end{array}\right|$ & $\begin{array}{l}291 \\
291\end{array}$ & & \begin{tabular}{l|l}
65 & 28 \\
66 & 30
\end{tabular} & $\mid \begin{array}{l}24 \\
23\end{array}$ & 18 \\
\hline \multirow{3}{*}{$\begin{array}{l}\text { Myomer } \\
\text { nr. } 9 .\end{array}$} & \multirow{3}{*}{$\begin{array}{l}87 \\
79 \\
80 \\
84 \\
87 \\
89 \\
84 \\
86 \\
83 \\
82 \\
83\end{array}$} & \multirow{2}{*}{\multicolumn{2}{|c|}{\begin{tabular}{|l|l|}
149 & 21 \\
148 & 21 \\
148 & 21 \\
150 & 21
\end{tabular}}} & \multirow{2}{*}{$\begin{array}{l}247 \\
4245 \\
3249\end{array}$} & \multirow{2}{*}{$\begin{array}{l}272 \\
271 \\
272\end{array}$} & \multirow{2}{*}{$\begin{array}{l}291 \\
291 \\
291\end{array}$} & 62 & \multirow{2}{*}{\begin{tabular}{|l|l|}
66 & 3 \\
66 & 3
\end{tabular}} & \multicolumn{2}{|c|}{\begin{tabular}{l|l|l}
32 & 25 & 19 \\
31 & 26 & 20
\end{tabular}} & \multirow[b]{2}{*}{ Averages } & \multicolumn{2}{|c|}{$84 \cdot 147$} & 7 & 245 & 271 & 916 & 367 & \multicolumn{3}{|c|}{\begin{tabular}{|l|l|l}
31 & 26 & 20 \\
\end{tabular}} \\
\hline & & & & & & & & & & & & 89 & $|154|$ & 220 & $|249|$ & $|272|$ & 291 & 66 & $66 \mid 29$ & & 19 \\
\hline & & \begin{tabular}{|l|}
150 \\
150 \\
151 \\
148 \\
150 \\
146 \\
146 \\
145
\end{tabular} & $\begin{array}{l}217 \\
216 \\
217 \\
215 \\
218 \\
219 \\
216 \\
216\end{array}$ & $\begin{array}{l}249 \\
248 \\
246 \\
245 \\
248 \\
248 \\
246 \\
246\end{array}$ & $\begin{array}{l}273 \\
273 \\
271 \\
271 \\
272 \\
273 \\
270 \\
272\end{array}$ & $\begin{array}{l}291 \\
291 \\
291 \\
291 \\
291 \\
291 \\
291 \\
291\end{array}$ & \begin{tabular}{|l|l}
66 & 6 \\
63 & \\
62 & \\
64 & \\
64 & 6 \\
63 & \\
64 & \\
62 & \\
\end{tabular} & \begin{tabular}{|l|l}
67 & 3 \\
66 & 3 \\
66 & 2 \\
67 & 3 \\
68 & 3 \\
73 & 2 \\
70 & 3 \\
71 & 3 \\
\end{tabular} & \begin{tabular}{|l|l|}
32 & 24 \\
32 & 25 \\
29 & 25 \\
30 & 26 \\
30 & 24 \\
29 & 25 \\
30 & 24 \\
30 & 26 \\
\end{tabular} & \begin{tabular}{|l|l|}
4 & 18 \\
5 & 18 \\
5 & 20 \\
6 & 20 \\
4 & 19 \\
5 & 18 \\
4 & 21 \\
6 & 19
\end{tabular} & $\begin{array}{c}\text { Myomer } \\
\text { nr. } 28 .\end{array}$ & $\begin{array}{l}89 \\
\mathbf{9 1} \\
\mathbf{9 1} \\
\mathbf{9 0} \\
\mathbf{9 0} \\
\mathbf{8 9} \\
\mathbf{8 4}\end{array}$ & $\left|\begin{array}{l}159 \\
158 \\
158 \\
154 \\
152 \\
152 \\
145\end{array}\right|$ & $\mid \begin{array}{l}225 \\
225 \\
222 \\
221 \\
218 \\
220 \\
215\end{array}$ & $\left|\begin{array}{l}259 \\
251 \\
250 \\
248 \\
247 \\
248 \\
247\end{array}\right|$ & $\left|\begin{array}{l}273 \\
273 \\
274 \\
272 \\
271 \\
272 \\
272\end{array}\right|$ & \begin{tabular}{l|}
291 \\
291 \\
291 \\
291 \\
291 \\
291 \\
291
\end{tabular} & \begin{tabular}{|l|l}
70 & 6 \\
$\mathbf{6 7}$ & 6 \\
$\mathbf{6 7}$ & 6 \\
$\mathbf{6 4}$ & $\mathbf{6}$ \\
$\mathbf{6 2}$ & 6 \\
$\mathbf{6 3}$ & 6 \\
$\mathbf{6 1}$ & $\mathbf{7}$
\end{tabular} & \begin{tabular}{l|l|}
66 & 34 \\
67 & 26 \\
64 & 28 \\
67 & 27 \\
66 & 29 \\
68 & 28 \\
70 & 32
\end{tabular} & $\begin{array}{l}24 \\
22 \\
24 \\
24 \\
24 \\
24 \\
25\end{array}$ & $\begin{array}{l}18 \\
18 \\
17 \\
19 \\
20 \\
19 \\
19\end{array}$ \\
\hline Averages & 84 & 148 & 216 & 247 & 272 & 291 & 64 & $\left.68\right|^{3}$ & $31|25|$ & 19 & Averages & 89 & 154 & 221 & 250 & 272 & 291 & 656 & $67 \mid 29$ & 24 & 19 \\
\hline $\begin{array}{l}\text { Myomer } \\
\text { nr. } 13 .\end{array}$ & $\begin{array}{l}82 \\
80 \\
83\end{array}$ & $\begin{array}{l}152 \\
148 \\
149\end{array}$ & $\begin{array}{l}221 \\
218 \\
219\end{array}$ & & $\begin{array}{l}274 \\
272 \\
274\end{array}$ & $\begin{array}{l}291 \\
291 \\
291\end{array}$ & $\begin{array}{l}70 \\
68 \\
65\end{array}$ & \begin{tabular}{l|l}
69 & 3 \\
70 & 3 \\
70 & 3
\end{tabular} & \begin{tabular}{l|l|}
30 & 23 \\
30 & 24 \\
30 & 25 \\
\end{tabular} & $\left|\begin{array}{l}17 \\
19 \\
17\end{array}\right|$ & $\begin{array}{c}\text { Myomer } \\
\text { nr. } 29 .\end{array}$ & $\begin{array}{l}89 \\
92\end{array}$ & $\left|\begin{array}{l}156 \\
155\end{array}\right|$ & 220 & 251 & $\mid \begin{array}{l}273 \\
271\end{array}$ & $\begin{array}{l}291 \\
291\end{array}$ & $\mid$\begin{tabular}{l|l}
67 & 6 \\
63 & 6 \\
\end{tabular} & \begin{tabular}{l|l|}
64 & 31 \\
64 & 29 \\
\end{tabular} & $\mid \begin{array}{l}22 \\
23\end{array}$ & $\begin{array}{l}18 \\
20 \\
-\end{array}$ \\
\hline & $\begin{array}{l}86 \\
88\end{array}$ & & 219 & 248 & $\begin{array}{l}273 \\
272\end{array}$ & & $68 t$ & \begin{tabular}{l|l}
65 & 2 \\
66 & 3
\end{tabular} & & 18 & Averages & 91 & 156 & 220 & 250 & 272 & 291 & 65 & $64 \mid 30$ & $\mathbf{2 3}$ & 19 \\
\hline & $\begin{array}{l}85 \\
82 \\
83 \\
78\end{array}$ & $\left|\begin{array}{l}148 \\
146 \\
145 \\
143\end{array}\right|$ & $\left|\begin{array}{l}216 \\
213 \\
214 \\
212\end{array}\right|$ & 2 & $\mid \begin{array}{l}272 \\
271 \\
270 \\
271\end{array}$ & $\begin{array}{l}291 \\
291 \\
291 \\
291\end{array}$ & \begin{tabular}{|l|}
63 \\
64 \\
62 \\
65
\end{tabular} & \begin{tabular}{l|l}
68 & 2 \\
67 & 3 \\
69 & 3 \\
69 & 3
\end{tabular} & \begin{tabular}{|l|l|}
29 & 27 \\
33 & 25 \\
32 & 24 \\
32 & 27 \\
\end{tabular} & $\begin{array}{l}19 \\
20 \\
21 \\
20\end{array}$ & $\begin{array}{c}\text { Myomer } \\
\text { nr. 33. }\end{array}$ & $\begin{array}{l}93 \\
95 \\
90 \\
92\end{array}$ & $\mid \begin{array}{l}158 \\
160 \\
158 \\
161\end{array}$ & $\begin{array}{l}223 \\
225 \\
223 \\
227\end{array}$ & $\begin{array}{l}254 \\
252 \\
249 \\
255\end{array}$ & $\left|\begin{array}{l}275 \\
273 \\
274 \\
274\end{array}\right|$ & $\left|\begin{array}{l}291 \\
291 \\
291 \\
291\end{array}\right|$ & \begin{tabular}{|c|c}
65 & 6 \\
65 & 6 \\
68 & 6 \\
69 & 6
\end{tabular} & \begin{tabular}{l|l|}
65 & 31 \\
65 & 27 \\
65 & 26 \\
66 & 28
\end{tabular} & $\begin{array}{l}21 \\
21 \\
25 \\
19\end{array}$ & $\begin{array}{l}16 \\
18 \\
17 \\
17\end{array}$ \\
\hline Averages & 83 & $\mid 148$ & $|217|$ & 247 & 272 & 291 & 65 & $\left.69\right|^{3}$ & $30|25|$ & 19 & & $\begin{array}{l}91 \\
92\end{array}$ & $\left|\begin{array}{l}156 \\
155\end{array}\right|$ & 22 & & $\begin{array}{l}273 \\
272\end{array}$ & $\begin{array}{l}291 \\
291\end{array} \mid$ & \begin{tabular}{l|l}
65 & 6 \\
63 & 6
\end{tabular} & & & \\
\hline $\begin{array}{c}\text { Myomer } \\
\text { nr. } 17 .\end{array}$ & $\begin{array}{l}85 \\
86\end{array}$ & $\left|\begin{array}{l}154 \\
155\end{array}\right|$ & $\begin{array}{l}221 \\
223\end{array}$ & $\begin{array}{l}248 \\
250\end{array}$ & $\begin{array}{l}273 \\
273\end{array}$ & 291 & 69 & \begin{tabular}{l|l}
67 & 2 \\
68 & 2
\end{tabular} & \begin{tabular}{l|l|}
27 & 25 \\
27 & 23
\end{tabular} & $\begin{array}{l}18 \\
18\end{array}$ & & $\begin{array}{l}86 \\
87\end{array}$ & $\left|\begin{array}{l}151 \\
153\end{array}\right|$ & $\left|\begin{array}{l}220 \\
228\end{array}\right|$ & $\left|\begin{array}{l}249 \\
246\end{array}\right|$ & $\left|\begin{array}{l}274 \\
276\end{array}\right|$ & $\begin{array}{l}291 \\
291 \\
\end{array}$ & $\mid$\begin{tabular}{l|l}
65 & 6 \\
66 & 7
\end{tabular} & \begin{tabular}{l|l|l}
69 & 29 \\
75 & 18
\end{tabular} & $\mid \begin{array}{l}25 \\
30\end{array}$ & $\begin{array}{l}17 \\
15\end{array}$ \\
\hline & 88 & 151 & & & & 291 & 636 & 683 & 30 & 20 & Averages & 91 & $|157|$ & 223 & 251 & $|274|$ & 291 & 66 & $66 \mid 27$ & $23 \mid 1$ & 17 \\
\hline & $\begin{array}{l}71 \\
85 \\
83 \\
80 \\
82 \\
81 \\
80\end{array}$ & \begin{tabular}{|l|}
100 \\
152 \\
150 \\
144 \\
148 \\
146 \\
146
\end{tabular} & \begin{tabular}{|l|}
224 \\
214 \\
215 \\
211 \\
216 \\
216 \\
215
\end{tabular} & $\begin{array}{l}2 \\
2 \\
2 \\
2 \\
2\end{array}$ & $\begin{array}{l}270 \\
270 \\
271 \\
271 \\
269\end{array}$ & \begin{tabular}{|l|}
291 \\
291 \\
291 \\
291 \\
291 \\
291 \\
291
\end{tabular} & \begin{tabular}{|l|l}
04 & \\
67 & \\
67 & \\
64 & 6 \\
66 & \\
65 & 7 \\
66 & 6 \\
\end{tabular} & \begin{tabular}{|l|l}
62 & 3 \\
62 & 3 \\
65 & 3 \\
67 & 3 \\
68 & 3 \\
70 & 3 \\
69 & 2 \\
\end{tabular} & \begin{tabular}{l|l|}
30 & 27 \\
32 & 23 \\
33 & 26 \\
30 & 25 \\
30 & 25 \\
29 & 25 \\
\end{tabular} & $\begin{array}{l}20 \\
21 \\
21 \\
20 \\
20 \\
22\end{array}$ & $\begin{array}{l}\text { Myomer } \\
\text { nr. 37. }\end{array}$ & $\begin{array}{l}99 \\
95 \\
94 \\
85 \\
92 \\
87\end{array}$ & $\begin{array}{l}165 \\
160 \\
161 \\
154 \\
153 \\
152\end{array}$ & $\begin{array}{l}228 \\
220 \\
226 \\
221 \\
221 \\
220\end{array}$ & $\begin{array}{l}253 \\
249 \\
252 \\
247 \\
250 \\
252\end{array}$ & $\begin{array}{l}275 \\
272 \\
273 \\
271 \\
272 \\
274\end{array}$ & \begin{tabular}{l|}
291 \\
291 \\
291 \\
291 \\
291 \\
291 \\
\end{tabular} & \begin{tabular}{|c|c}
66 & 6 \\
65 & 6 \\
67 & 6 \\
69 & 6 \\
61 & 6 \\
65 & 6
\end{tabular} & \begin{tabular}{l|l|}
63 & 25 \\
60 & 29 \\
65 & 26 \\
67 & 26 \\
68 & 29 \\
68 & 32
\end{tabular} & \begin{tabular}{|l|l|}
22 & 1 \\
23 & 1 \\
21 & 1 \\
24 & 2 \\
22 & 1 \\
22 & 1
\end{tabular} & $\begin{array}{l}19 \\
18 \\
20 \\
19 \\
17\end{array}$ \\
\hline Averages & 84 & 150 & 217 & 247 & 271 & 291 & 66 & 673 & $30|24|$ & 20 & Averages & 92 & 158 & 223 & 251 & 273 & 291 & 666 & \begin{tabular}{|l|l|}
64 & 28 \\
\end{tabular} & 221 & 18 \\
\hline $\begin{array}{c}\text { Myomer } \\
\text { nr. 21. }\end{array}$ & $\begin{array}{l}85 \\
89 \\
89 \\
85 \\
80 \\
88 \\
90 \\
85\end{array}$ & $\begin{array}{l}155 \\
157 \\
163 \\
153 \\
148 \\
153 \\
155 \\
150\end{array}$ & $\begin{array}{l}227 \\
233 \\
224 \\
219 \\
218 \\
217 \\
221 \\
218\end{array}$ & $\mid \begin{array}{l}247 \\
249 \\
249 \\
246\end{array}$ & $\begin{array}{l}275 \\
272 \\
274 \\
271\end{array}$ & $\begin{array}{l}291 \\
291 \\
291 \\
291 \\
291\end{array}$ & \begin{tabular}{|l|}
70 \\
68 \\
74 \\
68 \\
68 \\
65 \\
65 \\
65 \\
65
\end{tabular} & \begin{tabular}{|l|l}
72 & 2 \\
76 & 2 \\
61 & 3 \\
66 & 3 \\
70 & 2 \\
64 & 3 \\
66 & 2 \\
68 & 2
\end{tabular} & \begin{tabular}{l|l|}
23 & 22 \\
22 & 21 \\
30 & 20 \\
30 & 24 \\
29 & 26 \\
32 & 23 \\
28 & 25 \\
28 & 25 \\
\end{tabular} & $\begin{array}{l}19 \\
15 \\
17 \\
18 \\
18 \\
19 \\
17 \\
20\end{array}$ & $\begin{array}{l}\text { Myomer } \\
\text { nr. } 41 .\end{array}$ & $\begin{array}{l}99 \\
92 \\
92 \\
86 \\
90 \\
87 \\
81\end{array}$ & $\begin{array}{l}168 \\
164 \\
157 \\
153 \\
156 \\
156 \\
151\end{array}$ & $\begin{array}{l}235 \\
231 \\
225 \\
223 \\
221 \\
222 \\
220\end{array}$ & $\mid \begin{array}{l}257 \\
255 \\
250 \\
252 \\
251 \\
252 \\
248\end{array}$ & $\mid \begin{array}{l}274 \\
275 \\
273 \\
274 \\
272 \\
274 \\
272\end{array}$ & \begin{tabular}{l|}
291 \\
291 \\
291 \\
291 \\
291 \\
291 \\
291 \\
\end{tabular} & \begin{tabular}{|l|l}
69 & 6 \\
72 & 6 \\
65 & 6 \\
67 & 7 \\
66 & 6 \\
69 & 6 \\
70 & 6 \\
\end{tabular} & \begin{tabular}{l|l|}
67 & 22 \\
67 & 24 \\
68 & 25 \\
70 & 29 \\
65 & 30 \\
66 & 30 \\
69 & 28 \\
\end{tabular} & \begin{tabular}{|l|l}
17 & 1 \\
20 & 1 \\
23 & 1 \\
22 & 1 \\
21 & 1 \\
22 & 1 \\
24 & 1
\end{tabular} & $\begin{array}{l}16 \\
18 \\
17 \\
19 \\
17 \\
19\end{array}$ \\
\hline & $\begin{array}{l}84 \\
84\end{array}$ & $\begin{array}{l}148 \\
150\end{array}$ & & & $\begin{array}{l}271 \\
271\end{array}$ & $\begin{array}{l}291 \\
291\end{array}$ & $\left|\begin{array}{l}64 \\
66\end{array}\right|$ & \begin{tabular}{l|l}
68 \\
67 \\
3
\end{tabular} & \begin{tabular}{l|l|}
30 & 25 \\
31 & 23
\end{tabular} & & Averages & 90 & $|157|$ & $225 \mid$ & $|252|$ & $|273|$ & 291 & 68 & $67|27|$ & $|21| 1$ & \\
\hline Averages & 86 & 153 & 221 & 249 & 273 & 291 & 67 & $\left.68\right|^{2}$ & $28|23|$ & 18 & & 97 & 168 & $\mid 232$ & 260 & 278 & 291 & & & & \\
\hline $\begin{array}{c}\text { Myomer } \\
\text { nr. 25. }\end{array}$ & $\begin{array}{l}90 \\
92 \\
88 \\
91\end{array}$ & $\left|\begin{array}{l}158 \\
156 \\
161 \\
157\end{array}\right|$ & $\left|\begin{array}{l}224 \\
221 \\
226 \\
220\end{array}\right|$ & $\left|\begin{array}{l}255 \\
247 \\
250 \\
250\end{array}\right|$ & $\left|\begin{array}{l}274 \\
270 \\
273 \\
271\end{array}\right|$ & $\left|\begin{array}{l}291 \\
291 \\
291 \\
291\end{array}\right|$ & $\left|\begin{array}{l}68 \\
64 \\
73 \\
66\end{array}\right|$ & \begin{tabular}{|l|l}
66 & 3 \\
65 & 2 \\
65 & 2 \\
63 & 3
\end{tabular} & \begin{tabular}{l|l|}
31 & 19 \\
26 & 23 \\
24 & 23 \\
30 & 21
\end{tabular} & $\begin{array}{l}17 \\
21 \\
18 \\
20\end{array}$ & & $\begin{array}{l}95 \\
86 \\
94 \\
96\end{array}$ & $\mid \begin{array}{l}158 \\
157 \\
160 \\
166\end{array}$ & $\begin{array}{l}224 \\
225 \\
228 \\
233\end{array}$ & $\left|\begin{array}{l}249 \\
251 \\
254 \\
256\end{array}\right|$ & $\left|\begin{array}{l}272 \\
272 \\
275 \\
274\end{array}\right|$ & $\mid$\begin{tabular}{l|}
291 \\
291 \\
291 \\
291 \\
$\mid$
\end{tabular} & \begin{tabular}{|l|l}
63 & 6 \\
71 & 6 \\
66 & 6 \\
70 & 6
\end{tabular} & \begin{tabular}{l|l|}
66 & 25 \\
68 & 26 \\
68 & 26 \\
67 & 23
\end{tabular} & \begin{tabular}{|l|l}
23 & 1 \\
21 & 1 \\
21 & 1 \\
18 & 1
\end{tabular} & \\
\hline
\end{tabular}




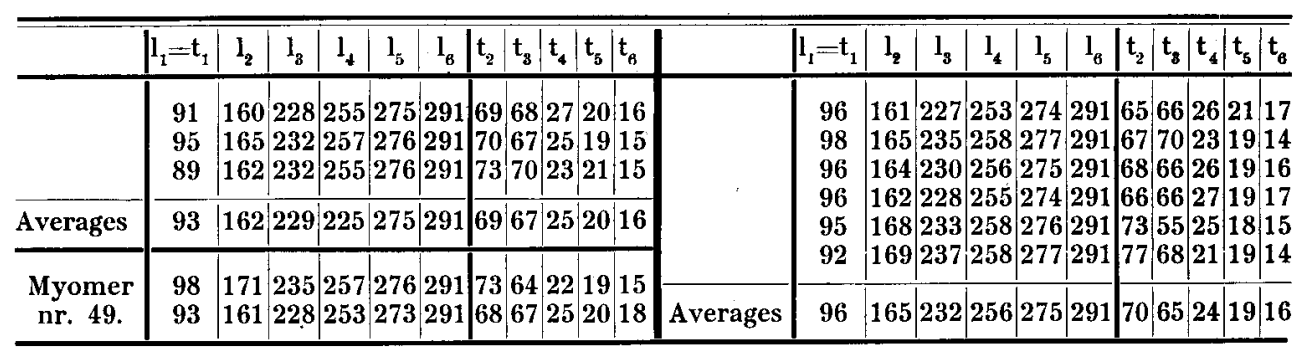

